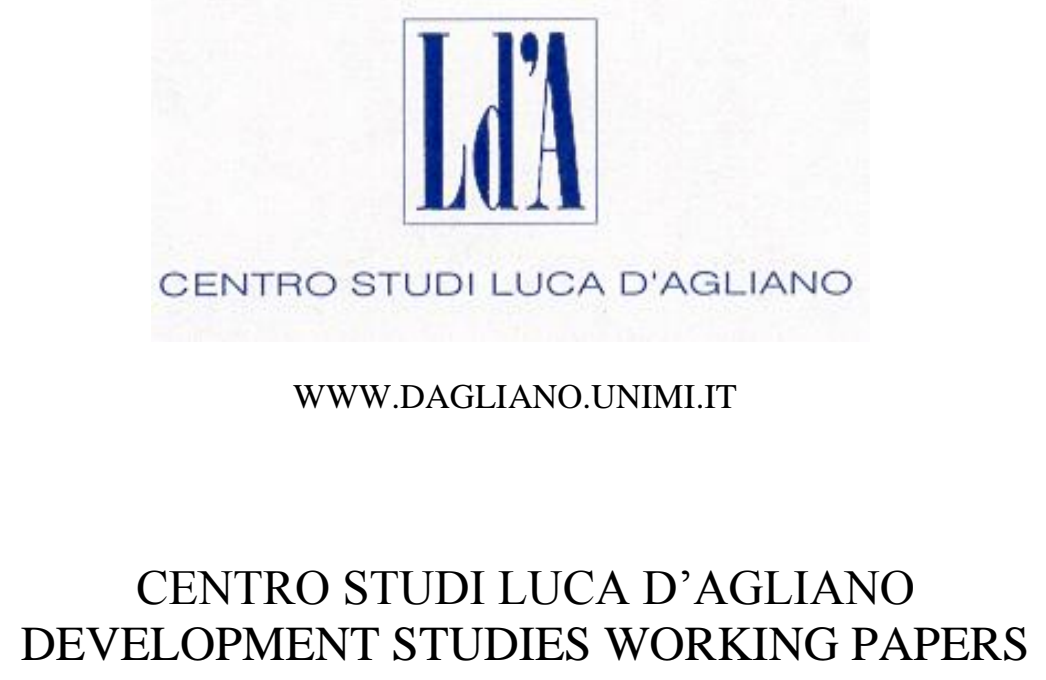

N. 287

April 2010

Networks, Sorting and Self-selection of Ecuadorian Migrants

Simone Bertoli*

* IAB, Institute for Employment Research and Robert Schuman Centre, European University Institute 


\title{
Networks, sorting and self-selection of Ecuadorian migrants
}

\author{
Simone BERTOLI²
}

\begin{abstract}
This paper provides new empirical evidence about the influence exerted by migration networks upon migrants' self-selection in education from the analysis of the recent process of Ecuadorian migration. The severe economic crisis that hit Ecuador in the late 1990s induced a massive wave of migration, from a country which was characterized by a substantial geographical variability in the size of migration networks. As Ecuadorian migrants opted for a variety of destination countries in the aftermath of the crisis, we estimate a multinomial logistic model to assess the impact of migration networks on both migrants' sorting and self-selection. The estimates are in line with the theoretical arguments which predict that migration networks increase the likelihood or the extent of a negative self-selection of the migrants with respect to education.
\end{abstract}

Keywords: migration, networks, self-selection, education, Ecuador.

JEL Classification: O15, J61, D31.

\footnotetext{
1 The author gratefully acknowledges the contribution by Herbert Brücker, Nicola Coniglio, Jesús Fernández-Huertas Moraga, José Hidalgo Pallares, Francesca Marchetta, Francesc Ortega, Hillel Rapoport. An earlier draft of this paper was presented at the Second Conference on Transnationality of Migrants, Louvain La Neuve, January 2009, and at a seminar at the Institut d'Analisi Economica, Barcelona, January 2010, and at the Migration and Economic Development Workshop organized by the Centro Luca D'Agliano, San Casciano, February 2010. The usual disclaimers apply.

2 IAB, Institute for Employment Research, Weddigenstr. 20-22, 90478, Nuremberg, Germany; email: sb3151@gmail.com.
} 


\section{INTRODUCTION}

There is a substantial literature on migrants' self-selection with respect to education, which combines theoretical arguments with empirical evidence, that substantially draws on the analysis of Mexican migration to the United States. ${ }^{3}$ The relevance of this topic can be hardly overstated, as different patterns of self-selection contribute to shape the effects of migration on the countries of origin and destination of the migrants.

A better understanding of the driving forces behind the individual decision to migrate, and of the ensuing aggregate pattern of self-selection, is hindered by the evidence about the magnitude and determinants of migration costs which remains limited, as HANSON [2008] argues. Migration costs vary substantially across destinations because of geographical and cultural factors, and because of differences in immigration policies. Furthermore, moving costs are influenced by the size of past migration flows, as the paper by CARRINGTON, DETRAGIACHE and VISHWANATH [1996] suggests. Past flows, which are commonly referred to as migration networks, reduce the psychic costs of moving, facilitate the access to the job market at destination, and can help would-be migrants to cover the monetary costs of migration through the transfer of remittances. ${ }^{4}$

Migration networks influence both the scale of migration and the sorting of migrants across countries, as they provide an incentive to replicate the destination choices of earlier migrants. Moreover, as the recent theoretical models by MCKENZIE and RAPOPORT [2007a] and BEINE, DOCQUIER and ÖZDEN [2009] predict, networks also shape migrants' self-selection with respect to education: the cost-reducing effect of an increase in the size of migration networks is unevenly distributed across different levels of schooling, so that the pattern of self-selection evolves endogenously as the migration process unfolds. Both models assume that the intensity of the reduction in migration costs induced by networks is stronger for individuals with a low level of education, so that an expansion of networks is expected to make negative selfselection more likely to occur. The evidence on the empirical relevance of this theoretical argument is still limited: MCKENZIE and RAPOPORT [2007a] and BEINE, DocQUiER and ÖZDEN [2009] find that larger networks do increase the likelihood or the extent of negative self-selection. The objective of this paper is to provide new empirical evidence based on the analysis of the recent process of Ecuadorian migration.

Ecuador recently experienced an unprecedented wave of migration, triggered by the severe economic crisis that hit the country in the late 1990s. More than 600,000 Ecuadorians left within a few years, with Spain and the United States attracting the greatest share of the migrants (Bertoli, Fernández-Huertas Moraga and Ortega, 2010). Before the crisis, the Ecuadorian community in Spain was limited in size, while Ecuador had long-established

\footnotetext{
3 See Chiquiar and HANSON [2005], MCKenzie and RAPOPORT [2007a], IbARRARÁN and LUBOTSKY [2007], and FERNÁNDEZ-HUERTAS MORAGA [2008a, 2008b] for recent analyses.

${ }^{4}$ See ORRENIUS and ZAVODNY [2005] and HANSON and MCINTOSH [2008] for empirical evidence on the role of migration networks in influencing the scale of Mexican migration to the United States.
} 
migration networks with the United States, dating back to the late 1950s when Ecuadorians began to move to New York from two Southern Andean provinces, Azuay and Cañar (KYLE, 2000). The variety in the size of established migration networks across destinations - and their geographical variability within Ecuador - provides an important analytical opportunity to assess the role of past migration flows in shaping current migration decisions.

The analysis draws on a labour market survey, the Encuesta Nacional sobre el Empleo $y$ Desempleo en el Area Urbana y Rural, ENEMDU henceforth, collected in December 2005, which provides data on resident and migrant members of the sampled households. This dataset is matched with originally collected data from the Superintendencia de Bancos y Seguros, the public institution which supervises the banking sector, about the geographical location of the branches of the 16 domestic banks which failed at the time of the crisis, and with data from the Ecuadorian Central Bank, the National Statistical Office, INEC, and the Ministry of Education to control for other factors that can be expected to influence the decision to migrate. We also employ data collected in the two major destinations, namely the 2005 to 2008 rounds of the American Community Survey for the United States (RugGLES et al., 2008), and the 2007 Encuesta Nacional de Inmigrantes for Spain, to correct for the inability of the ENEMDU 2005 to capture migrants belonging to whole households which moved abroad, and to gauge the relevance of the possible reluctance of the interviewees to disclose information about illegal migrants.

The paper is structured as follows: section 2 provides a brief overview of the theoretical literature on the relationship between networks and self-selection. Section 3 describes the salient features of the recent process of Ecuadorian migration, and section 4 presents the data sources. Section 5 provides the descriptive statistics, section 6 introduces the estimation method and the identification strategy, while section 7 discusses the possible threats to the proposed strategy. Section 8 presents the results from the econometric analysis, and section 9 concludes.

\section{Migration COStS, Networks AND SELF-SELection}

BORJAS [1988], who extends the analysis in BORJAS [1987], applies the Roy's model [1951] to identify the relative return to income-generating characteristics in the origin and in the destination country as the key factor in shaping pattern of migrants' self-selection in observables. A pattern of negative selection with respect to education emerges if its relative return is lower at destination than in the country of origin. ${ }^{5}$ As BORJAS [1988] himself evidences, this prediction is valid as long as moving costs do not correlate with the income-generating characteristics of would-be migrants; conversely, a significant correlation

\footnotetext{
${ }^{5}$ The recent paper by GROGGER and HANSON [2008] challenges the role that BORJAS [1987] attributes to relative return to education in driving the pattern of migrant's self-selection, as international migration data are better explained by a simple linear utility model where it is the absolute difference in wages across different levels of schooling that determines how migrants are self-selected with respect to education.
} 
between the two could produce a different pattern of self-selection than the one that would be predicted on the basis of relative returns alone. BORJAS [1988] suggests that there is no clear reason why moving costs should be either positively or negatively correlated with incomegenerating characteristics.

On the other hand, CHISWICK [1999] argues that moving costs are lower for high than for low skilled individuals, as "the same investment in migration may require fewer units of time or fewer units of out-of-pocket costs for the more able". CHIQUIAR and HANSON [2005] present a model where migration costs are assumed to be decreasing in the level of schooling of a would-be migrant. Such a specification entails that an intermediate or even a positive pattern of self-selection can arise even when the relative returns to skills are lower at destination.

CHIQUIAR and HANSON [2005] warn the readers that "one caveat is that our analyis ignores migration networks", which appear to be relevant in the case of migration from Mexico to the United States that they analyze, as MUNSHI [2003] and WoOdRUFF and ZENTENO [2007] suggest. MCKENZIE and RAPOPORT [2007a] propose an extension of the theoretical model by CHIQUIAR and HANSON [2005] which specifically addresses this caveat. In a framework where education is exogenously given and immigration policies are not selective with respect to education, they model time-equivalent moving costs through a function that is decreasing both in the years of schooling and in the size of migration networks, and they further assume the cross-derivative with respect to these two variables to be positive. This entails that an increase in the size of migration networks reduces migration costs more the lower it is the level of schooling of a would-be migrant. This functional specification - jointly with the assumption that schooling is characterized by a non-increasing probability density function - drives the main theoretical prediction by MCKENZIE and RAPOPORT [2007a]: migrants' average level of schooling falls with the size of networks, and that this increases the likelihood or the extent of a migrants' negative self-selection in education. The estimates by MCKENZIE and RAPOPORT [2007a], based on the 1997 ENADID survey, provide support to their theoretical prediction, as a negative selfselection is found in Mexican communities with larger migration networks, while immigrants are positively self-selected from communities with a limited past record of international migration.

The model proposed by BEINE, DOCQUIER and ÖZDEN [2009] similarly suggests that larger migration networks - that they refer to as diasporas - exert a negative effect on the selection of migrants, as "a larger diaspora lowers migration and visa costs for all skill levels but the intensity of reduction is stronger for low-skilled individuals". BEINE, DOCQUIER and ÖZDEN [2009] assess the empirical relevance of their theoretical prediction through the analysis of macro data on bilateral migration flows, broken down by educational attainment. Their evidence is consistent with MCKENZIE and RAPOPORT [2007a], as they conclude that larger diasporas negatively influence the skill composition of migration flows. 


\section{ECUADORIAN MIGRATION}

The international migration history of Ecuador dates back to the late 1950s and early 1960s, when a sharp decline in the demand for Panama and Monte Christi hats in the United States, the main export market, led to a collapse in the weaving of paja toquilla, that had traditionally represented the main non-farm economic activity for the rural households of the Southern Andean provinces of Azuay and Cañar. The exporters of Panama hats were the first to migrate to the United States, as they could rely on the connections they had previously established through their trading activities, and were then followed by the farmers that had been hit hard by the loss of this source of income (KYLE, 2000; JOKISCH, 2001; JOKISCH and PRIBILSKY, 2002). The network of intermediaries which used to mediate the procurement of straw hats for exporters turned into "an integrated network of tramitadores, or facilitators, who provide[d] the range of legal and illegal services needed to make a clandestine trip to the United States" (KYLE, 2000).

Migration maintained for a long time a distinct regional character and a limited aggregate scale, as the Ecuadorian economy grew at an average rate of 7.5 percent per year between 1965 and 1980 (BECKERMAN, 2002), and the discovery of oil fields in the Amazonian region opened up new opportunities for internal migration, which had traditionally been seasonal and directed towards the banana and sugar plantations in the provinces along the coast. Even the external debt crisis that hit Latin American countries in the early 1980s failed to generate a significant country-wide process of international migration, and the flows remained limited in size (RAmírez Gallegos and Ramírez, 2005). At the same time, the crisis intensified migration out of Azuay and Cañar, as "the economic crisis was national, not regional, which meant that migration to other regions of Ecuador was now financially risky and unattractive" (KYLE, 2000). This picture changed dramatically in the late 1990s, when the country suffered from a severe financial and economic crisis. The price of oil, that constitutes the largest revenue item in the Ecuadorian Balance of Payments, hit a historical low in 1998, and the coastal provinces suffered from the floods induced by El Niño in the same year, which caused major infrastructural disruptions and severely hurt the export-oriented agricultural sector. ${ }^{6}$ This series of events aggravated the macroeconomic instability of the country, and led to the collapse of the domestic currency, the sucre, and to a large-scale banking crisis. The freeze of all bank accounts declared in March 1999, in a desperate attempt to stop massive withdrawals, precipitated the country in a deep recession, with the per capita GDP falling by 7.6 percent in real terms over the year. The government decided to adopt the dollar as a legal tender of exchange in January 2000, to avoid the incipient risk of hyperinflation. By that time, 16 out of 36 domestic banks had already been closed or had gone under public stewardship (IMF, 2000).

\footnotetext{
${ }^{6}$ Economic losses due to El Niño amounted to $\$ 2.6$ billion, 13 percent of the Ecuadorian GDP in 1998 (IMF, 2000 ).
} 
The crisis induced a huge rise in the poverty incidence in urban areas from 35 percent in 1998 to 68 percent in 2000 (LARREA, 2004), and it simultaneously triggered an unprecedented wave of international migration, that assumed for the first time a country-wide character. Approximately 100,000 migrants left every, as Ecuadorian households attempted to mitigate the adverse effects of the crisis through the transfer of remittances (BRown, 2006).

The first salient difference between the past and the recent wave of Ecuadorian migration relates to the sorting of the migrants across countries, as most of those who moved in the aftermath of the crisis headed towards Spain rather than opting for the United States. At the time of the crisis, the United States offered little options but family reunification provisions for legal migration (Bertoli, Fernández-Huertas Moraga and Ortega, 2010), and the costs for migrating illegally from Ecuador to the United States had increased substantially since the mid1990s with the start of the Operation Gatekeeper. KYLE [2000] signal that the costs of purchasing fake visas or paying smugglers ranged between $\$ 6,000$ and $\$ 10,000$. $^{7}$ Conversely, Ecuadorians had the opportunity to enter legally into Spain, as a bilateral agreement signed in 1963 between the two countries granted them a visa waiver for a period of up to 3 months. ${ }^{8}$ The data from the 2007 Encuesta Nacional de Inmigrantes evidence that the Ecuadorians who entered Spain after 1998 sustained direct costs of migration amounting to $\$ 1,800$ per individual. Moreover, while the per capita income in Spain was less than one fifth of the one prevailing in the United States in 1963, this ratio had moved up to one half in 1998, at the onset of the crisis (WORLD BANK, 2008). Thus, the huge gap in the monetary costs of moving to the two countries - at a time when the widespread banking crisis had made liquidity constraints rather binding for would-be migrants - and the linguistic and cultural proximity between Ecuador and Spain induced most migrants to opt for this destination.

Still, it is important to signal that this pattern records a notable exception, represented by the provinces of Azuay and Cañar, whose migrants were still heading towards the United States. A labor market survey conducted in 2003 by the Facultad Latinoamericana de Ciencias Sociales in the three major cities of Quito, Guayaquil and Cuenca revealed that the share of migrants who went to the United States was close to 25 percent for the first two cities, while it reached 82 percent for the latter, which belongs to the province of Azuay (FLACSO, 2004).

While migration used to be a predominantly rural phenomenon (KYLE, 2000), the recent migrants came mostly from the urban areas of the country (ORTIZ MOYA and GUERRA PÁEZ, 2008), and this feature can be related to the characteristics of the late 1990s crisis and to the role of migration networks in shaping migration costs and migrants' self-selection. The effects of the crisis spread all over the country, but - with the possible exception of the Coastal provinces affected by El Niño rains - the urban areas were more severely hit. Besides the

\footnotetext{
7 The Ecuadorians who wanted to migrate illegally to the United States used to fly legally to Mexico, and then attempted to cross the border; but as Mexico started to cooperate with the Operation Gatekeeper and tightened the controls on transit migrants, the Ecuadorians began to "board overcrowded fishing trawlers destined for Mexico or Guatemala en route to the United States" (JOKISCH and PRIBILSKY, 2002).

${ }^{8}$ The requirement of a visa was reintroduced on August 3, 2003.
} 
freeze of the bank accounts that substantially reduced the real value of their savings, urban households suffered from the suspension of the wage payment to public employees declared by the government in 1999 (ACOSTA, LÓPEZ and VILLAMAR, 2004), and by the slash in real wages induced by the sharply undervalued conversion rate at which dollarization was implemented. ${ }^{9}$ Furthermore, given the limited to nonexistent past migration history that characterized the whole country but Azuay and Cañar at the end of the 1990s, the marked differences in both economic and educational conditions along the rural-urban divide in Ecuador contribute to further explain the observed over-representation of urban households among migrant ones. In the early stages of a migration process "only the middle class of the wealth distribution may have both the means and the incentives to migrate", as MCKENZIE and RAPOPORT [2007b] argue.

\section{DATA SOURCES}

The Encuesta Nacional sobre el Empleo y Desempleo en el Area Urbana y Rural is a quarterly labour market survey collected by the INEC; three rounds a year cover only the urban areas, as its official ENEMDU acronym suggests, while once a year, in December, the survey extends also to the rural areas. The INEC adopted a broad definition of household membership in the December 2005 round: this definition includes household members who reside outside the country, in line with the reccomendation by ÜNALAN [2005] for international migration surveys. The survey provides information about the gender, age, marital status, relationship to household head, and educational attainment at the time of migration of all migrant members, provided that at least another household member was still in Ecuador at the time of the survey. Furthermore, this round of the ENEMDU survey included also a whole section dedicated to international migration and remittances, that contains additional information about the year of migration, the country of current residence, the amount of remittances sent by the migrant over the 12 months prior to the survey.

The sample consists of 18,357 households, and its design ensures representativeness at the level of each of the 21 in-land Ecuadorian provinces. ${ }^{10} \mathrm{~A}$ limit of this data source is that it undercounts migrants: it suggests that 245,000 individuals left the country between 1998 and 2005, well below the figures reported by most authors and what destination countries data source suggest (Bertoli, Fernández-Huertas Moraga and ORTEGA, 2010). Two factors - which generally influence migration surveys conducted in origin countries - play a distinct role in explaining this undercount: first, the possible reluctance of the respondents to disclose information about a household member who does not hold a legal residence permit in the destination country and, second, whole households migration, which - by construction - goes unrecorded in surveys conducted in the countries of origin.

\footnotetext{
${ }^{9}$ The public wage bill fell by 56 percent in real terms from 1998 to 2000 (BECKERMAN and CORTÉs DOUGLAS, 2002).

${ }^{10}$ The Galapagos Islands, that host just 0.15 percent of the Ecuadorian population, are not covered by the survey.
} 
With respect to the first factor, data from various issues of the Yearbook of Immigration Statistics reveal that 60,154 out of 71,034 Ecuadorians who became legal permanent residents in the United States between 1998 and 2005 did so thanks to family-based preferences $(19,757)$ or because they were relatives of US citizens $(40,397),{ }^{11}$ while only 8,365 individuals had access to employment-based preferences (UNITED STATES, DEPARTMENT OF HOMELAND SECURITY). This entails that illegal routes were the only available option for would-be migrants who did not have a relative in the United States. ${ }^{12}$ Conversely, Ecuadorian migrants could enter Spain legally without a visa, overstay the 3-month period and then wait for one of the recurrent Spanish regularizations of undocumented immigrants, that were implemented in 2000, 2001 and 2005.

With respect to the second factor, the data reported above from the Yearbook of Immigration Statistics confirm that whole household migration towards the United States could be substantial in the post-crisis period. With respect to Spain, the Encuesta Nacional de Inmigrantes evidences that approximately one third of the Ecuadorians who arrived in the aftermath of the crisis is married and with the spouse present, a status that has been used in the literature as a proxy for whole household migration (MCKENZIE and RAPOPORT, 2007a). Section 6 will discuss in detail how these two facets of undercounting can pose a threat to our identification strategy, and what can be done to address the ensuing concerns.

The ENEMDU 2005 is combined with data from the Superintendencia de Bancos y Seguros, the monitoring authority of the banking and insurance sectors, which have been originally collected for this paper. The Superintendencia has data on the geographical distribution of the bank branches at the county level. Most interestingly for the purpose of our analysis, it also provides the data on the distribution of the banks which are no longer active, as they failed during the crisis of the late 1990s. The historical record for these domestic banks refers to the time when their failure was declared. We have thus been able to collect the data on the geographical distribution of the head offices and branches of the 16 banks which did not survive the collapse of the banking system. ${ }^{13}$

\section{Descriptive StATISTics}

Figure 1 reports, for each province, the share of households that had at least one migrant member in the United States before 1998. Figure 1 is based on data from the ENEMDU 2005, and it thus captures only those pre-crisis migrants who were still alive in December 2005, and who had not broiught their household with them to the United States. Hence, Figure 1 provides

\footnotetext{
11 The 2000 US Census reveals that 102,550 out of the 298,650 individuals who were born in Ecuador had been naturalized.

12 HOEFER, RYTinA and BAKER [2008] estimate that on average 10,000 Ecuadorians entered illegally every year between January 2000 and January 2006.

13 The banks that failed between 1999 and 2000 are Aserval, Azuay, Bancomex, Continental, de Credito, Filanbanco, Finagro, Financorp, Popular, Prestamos, Previsora, Progreso, Occidente, Solbanco, Tungurahua and Union, and the Superintendencia provides information about the geographical location of their 505 branches.
} 
an underestimate the actual size of pre-crisis migration networks. With these caveats in mind, it can be observed that Azuay and Cañar stand out from the other Ecuadorian provinces, in line with the arguments presented in section 3.

FIGURE 1.

Share of households with at least one migrant to the United States before 1998

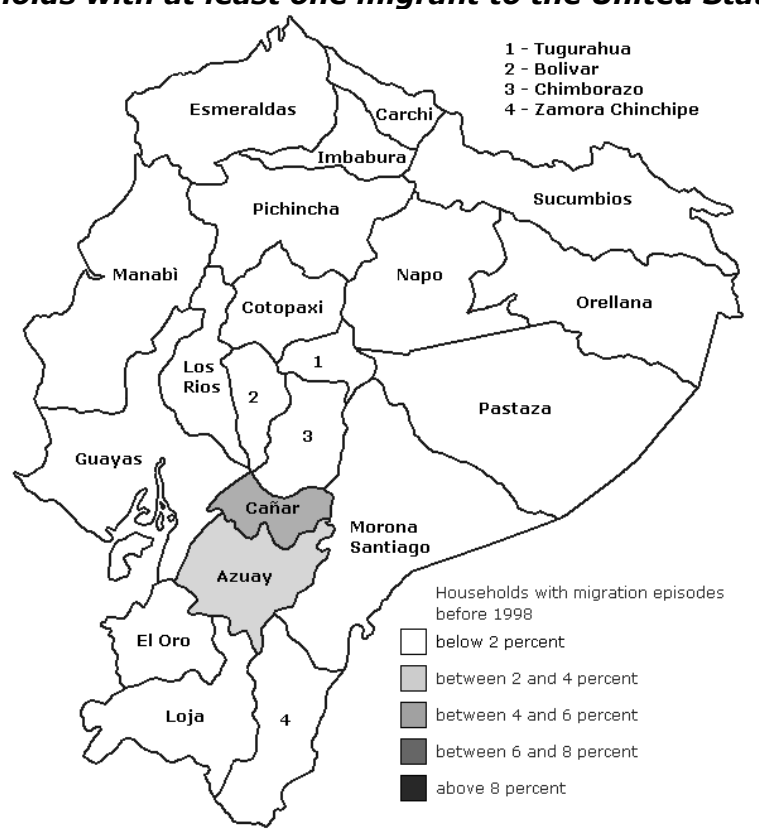

Source: author's elaboration on ENEMDU 2005

Unsurprisingly, given the influence exterted by past migration flows on current moving costs, Azuay and Cañar are among the provinces that also recorded the largest scale of migration in the post-crisis period, as Figure 2 shows.

FIGURE 2.

Share of households with at least one migration episode after 1998

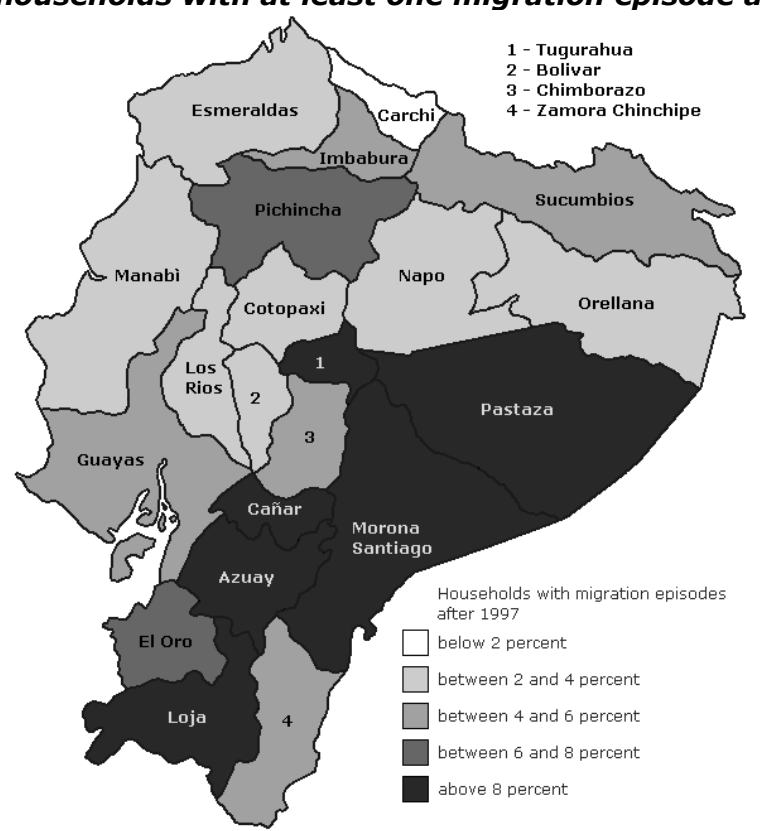

Source: author's elaboration on ENEMDU 2005 
The country-wide character of the recent wave of international migration hides substantial geographical differences with respect to migrants' sorting across destinations: the shares of migrants from Azuay and Cañar who opted for the United States in the aftermath of the late-1990s crisis stand at 82.3 percent, while the corresponding figure for the other 19 provinces is just 17.4 percent, and 63.8 of the migrants from the rest of the country moved to Spain. The extent of migration networks prior to the crisis did not exert an influence on migrants' sorting alone, but apparently also on their self-selection with respect to education. The average number of years of schooling of the migrants who left Azuay and Cañar after the crisis and were aged between 19 and 49 years at the time of migration is 8.1, while the corresponding figure for the rest of the country stands at 11.7 years. This difference is impressive, and it is matched by a non significant difference in the average years of schooling among the stayers in the same age group: the average number of years of schooling for stayers is 9.6 in Azuay and Cañar, while the average is 9.8 in the rest of Ecuador.

TABLE 1.

Descriptive statistics across migrant status and destination countries

\begin{tabular}{|c|c|c|c|c|c|c|c|}
\hline \multirow[b]{3}{*}{ Variables } & \multirow[b]{3}{*}{ Observations } & \multicolumn{6}{|c|}{ Individuals aged 19-49 } \\
\hline & & \multirow[b]{2}{*}{ All } & \multirow[b]{2}{*}{ Stayers } & \multicolumn{4}{|c|}{ Migrants } \\
\hline & & & & All & US & Spain & RoW \\
\hline Migrants after 1998 & 27,188 & 0.034 & 0 & 1 & 1 & 1 & 1 \\
\hline Migrants to the United States & 27,188 & 0.007 & 0 & 0.196 & 1 & 0 & 0 \\
\hline Migrants to Spain & 27,188 & 0.021 & 0 & 0.622 & 0 & 1 & 0 \\
\hline $\begin{array}{l}\text { Migrants to the Rest of the } \\
\text { World }\end{array}$ & 27,188 & 0.006 & 0 & 0.182 & 0 & 0 & 1 \\
\hline Resident in rural areas & 27,188 & 0.243 & 0.244 & 0.218 & 0.408 & 0.182 & 0.134 \\
\hline Female & 27,188 & 0.513 & 0.516 & 0.455 & 0.349 & 0.476 & 0.496 \\
\hline Married & 27,188 & 0.397 & 0.396 & 0.432 & 0.537 & 0.44 & 0.293 \\
\hline Age & 27,188 & $\begin{array}{l}32.4 \\
(8.9)\end{array}$ & $\begin{array}{l}32.5 \\
(8.9)\end{array}$ & $\begin{array}{l}28.9 \\
(7.9)\end{array}$ & $\begin{array}{l}29.4 \\
(8.4)\end{array}$ & $\begin{array}{l}29.2 \\
(7.7)\end{array}$ & $\begin{array}{l}27.7 \\
(8.2)\end{array}$ \\
\hline Years of education & 27,188 & $\begin{array}{c}9.8 \\
(4.6)\end{array}$ & $\begin{array}{c}9.8 \\
(4.6)\end{array}$ & $\begin{array}{l}11.3 \\
(3.8)\end{array}$ & $\begin{array}{l}10.1 \\
(4.5)\end{array}$ & $\begin{array}{l}11.2 \\
(3.5)\end{array}$ & $\begin{array}{l}12.8 \\
(3.4)\end{array}$ \\
\hline Indigenous households & 27,188 & 0.113 & 0.113 & 0.112 & 0.097 & 0.113 & 0.123 \\
\hline Working age members & 27,188 & $\begin{array}{c}3.5 \\
(1.7)\end{array}$ & $\begin{array}{c}3.4 \\
(1.7)\end{array}$ & $\begin{array}{c}4.3 \\
(1.9)\end{array}$ & $\begin{array}{l}3.8 \\
(1.8)\end{array}$ & $\begin{array}{c}4.9 \\
(1.9)\end{array}$ & $\begin{array}{c}4.4 \\
(2.1)\end{array}$ \\
\hline Extent of bank failures & 27,188 & 0.074 & 0.073 & 0.08 & 0.09 & 0.076 & 0.081 \\
\hline Past migration & 27,188 & 0.01 & 0.008 & 0.05 & 0.09 & 0.039 & 0.045 \\
\hline $\begin{array}{l}\text { Migration networks, county } \\
\text { level }\end{array}$ & 27,188 & 0.01 & 0.01 & 0.014 & 0.028 & 0.011 & 0.010 \\
\hline Asset index & 27,188 & $\begin{array}{c}54.3 \\
(18.9)\end{array}$ & $\begin{array}{c}54.1 \\
(18.9)\end{array}$ & $\begin{array}{c}61.9 \\
(14.8)\end{array}$ & $\begin{array}{c}61.4 \\
(17.2)\end{array}$ & $\begin{array}{c}61.4 \\
(13.6)\end{array}$ & $\begin{array}{c}64.9 \\
(14.6)\end{array}$ \\
\hline
\end{tabular}

Note: standard deviation within parenthesis; statistics restricted to the 88 counties with at least 50 sampled households; age and years of education for migrants are measured at the time of migration; extent of bank failures is the number of branches of failed banks within the county per 1,000 inhabitants.

Source: authors' elaboration on ENEMDU 2005 and data from the Superintendencia de Bancos y Seguros 
Table 1 reports descriptive statistics on the variables which are likely to influence the pattern of migrants' self-selection, broken down across migrant status and destination. Given that the central interest of the paper resides in the analysis of the role of migration networks in influencing migrants' self-selection, we restrict the sample to the counties with at least 50 sampled households, to improve the reliability of the measure of the size of migration networks at the county level, as in MCKENZIE and RAPOPORT [2007a].

The share of individuals from rural areas among the migrants is roughly in line with the corresponding share in the resident population, but this hides substantial differences across destinations: individuals who resided in rural areas represent 40.8 percent of the migrants to the United States, while the corresponding figures for Spain and the Rest of the World stand at 18.2 and 13.4 percent respectively. Males are markedly overrepresented among migrants to the United States, though this could be partly due to the greatest role of family reunification provisions in driving recent female migration (SÁNCHEZ, 2004), while migration flows towards other destinations are gender-balanced. Not surprisingly, the size of migration networks - both at the household and at the county level - is higher for migrants to the United States: 9 percent of the individuals who moved to this country came from households who already had a member there in the pre-crisis period, while the corresponding figure for migrants to Spain stands at 3.9 percent.

On average, migrants to the United States have 10.1 years of education, while migrants to Spain and to the Rest of the World have completed 11.2 and 12.8 years of schooling. The difference across destinations - which is statistically significant - can be related to the higher share of individuals from rural areas which moved to the United States, and to the predominant role that migrants from Azuay and Cañar have in influencing aggregate figures for the United States: migrants from these two provinces represent 35.8 percent of the post1998 migrants, ${ }^{14}$ although Azuay and Cañar account for just 6.6 percent of the Ecuadorian population, according to the 2001 Census.

We also computed a measure of household assets following FILMER and PRITCHETT [2001], aggregating 12 variables providing information on the ownership of durable goods and the characteristics of the household's dwellings through principal component analysis, ${ }^{15}$ as the exposure to the effects of the late-1990s crisis is likely to correlate with a household's economic condition. As Table 1 evidences, the asset index - which has been rescaled between 0 and 100, and that captures 36.3 percent of the variance in asset holdings - is for migrants than for non migrants. Still, it is necessary to stress that this measure is based on data referring to the time of the survey, and it is thus likely to be endogenous with respect to migration itself. Households - which might have drawn on their assets to cover migration costs

\footnotetext{
${ }^{14}$ The figure goes up to 48.3 percent if we introduce the restrictions with respect to age at migration used in Table 1.

15 The variables are the number of rooms per adult equivalent, dummies signaling whether the household owns a motorcycle, a car, and other referring to the characteristics of the dwelling: whether it has a wooden or cement floor, it is connected to the sewage network, it has electricity, water, a telephone line, a kitchen with oven, a fridge, a television, a computer.
} 
- can finance the purchase of the goods that are included in the index with the transfers they receive from the migrants, and the data are suggestive that the influence exerted by remittances could, indeed, be substantial.

FIGURE 3.

Evolution of the asset index with respect to the years since migration

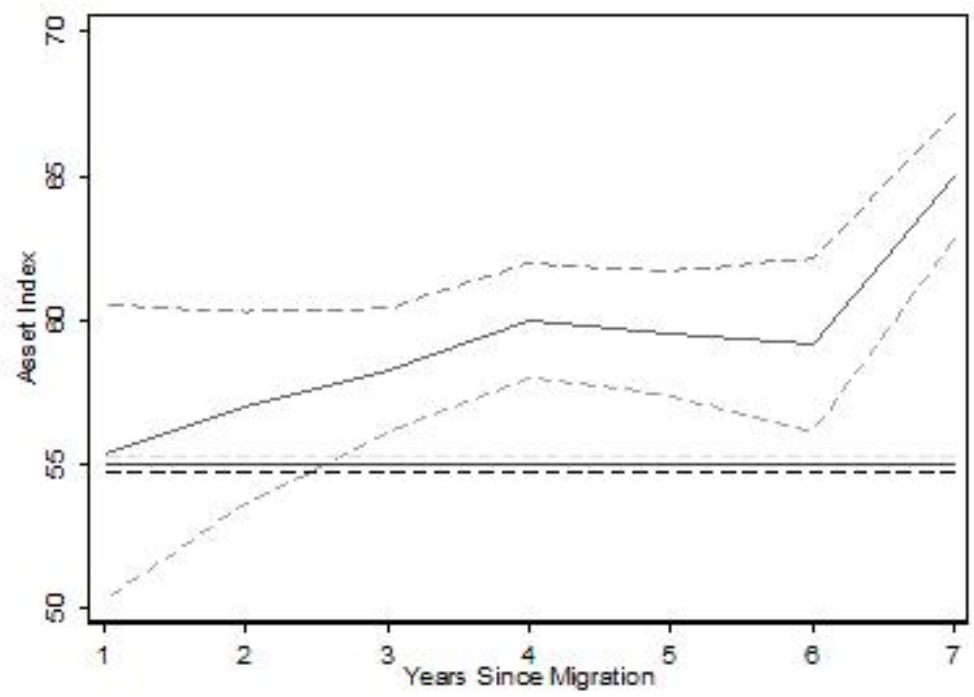

Note: dashed lines denote a 95 percent confidence intervals for migrants and stayers Source: author's elaboration on ENEMDU 2005

The upward-sloping line in Figure 3 is obtained by plotting the average value of the household asset index against the time elapsed since migration: although the index is higher than the average for stayers for any number of years since migration, it increases by 9.4 points, approximately half of a standard deviation over the whole population, once we move from 1 to 7 years since migration. Some authors - such as ACOSTA, CALDERÓN, FAJNZYLBER and LóPEZ [2008] - employ the asset index in an analysis of the determinants of the choice to migrate under the implicit assumption that it is more reflective of past saving behaviour rather than of the effects of remittances, but this assumption would be at best inadequate in the case at hand. The concern about the endogeneity of the asset index does not allow to include this variable in the econometric analysis, where we conversely rely on the per capita income level at the province level, and a proxy for the distribution of the effects of the collapse of the banking system at the county level to control for differences in economic conditions across migrant-sending communities.

\section{ESTIMATION METHODS AND IDENTIFICATION STRATEGY}

The goal of the multivariate analysis is to gain a better understanding of the role of migration networks in influencing the pattern of self-selection of the Ecuadorian migrants across four alternative location choices: staying in Ecuador, migrating to the United States, migrating to 
Spain, and migrating to any other foreign destination. ${ }^{16}$ The ENEMDU 2005 provides information about the year of the various migration episodes, and this allows us to distinguish the migrants that left after 1998, when the crisis began to unfold its effects, from those we had moved out of Ecuador before. As described in section 5, we measure the size of migration networks at the county level as the share of households who had a migrant in the United States before 1998, and we rely on this variable to analyze the determinants of the self-selection of the migrants who left in the 1998-2005 period.

The utility that the $j$-th individual derives from choosing one of the four possible locations is given by:

$$
\mathrm{u}_{\mathrm{jk}}=\mathbf{x}_{\mathrm{j}}^{\prime} \beta_{\mathrm{k}}+\varepsilon_{\mathrm{jk}}, \mathrm{k}=1, \ldots, 4
$$

If the stochastic component $\varepsilon_{\mathrm{jk}}$ in Eq. (1) is assumed to be independently and identically distributed across the four destinations and it follows a Type-1 Gumbel distribution, then the probability that the $j$-th individual opts for the $k$-th destination, $\mathrm{p}_{\mathrm{jk}}$, is given by:

$$
\mathrm{p}_{\mathrm{jk}}=\frac{\exp \left(\mathbf{x}_{\mathrm{j}}^{\prime} \boldsymbol{\beta}_{\mathrm{k}}\right)}{\sum_{\mathrm{d}=1}^{4} \exp \left(\mathbf{x}_{\mathrm{j}}^{\prime} \boldsymbol{\beta}_{\mathrm{d}}\right)}, \mathrm{k}=1, \ldots, 4
$$

and it can thus be estimated with a multinomial logistic model, where the vector of coefficients $\boldsymbol{\beta}_{1}$, which refers to staying in Ecuador, is normalized to 0 . The appropriateness of the assumption on the error structure, which rules out the possibility that the error term could be correlated across destinations, will be tested following the logic of HAUSMAN and MCFADDEN [1984].

The probability of opting for the $k$-th destination over the probability of the base outcome is given by:

$$
\frac{p_{j k}}{p_{j 1}}=\exp \left(\mathbf{x}_{j}^{\prime} \boldsymbol{\beta}_{k}\right), k=2, \ldots, 4
$$

Labeling as $x_{1}$ and $x_{2}$ the years of education and the size of the migration network, while their interaction is denoted by $x_{12}$, the marginal effect of migration networks upon the odds ratio is given by:

$$
\frac{\partial \frac{p_{j k}}{p_{j 1}}}{\partial x_{2 j}}=\left(\beta_{2 k}+\beta_{12 k} x_{1 j}\right) \exp \left(\mathbf{x}_{j}^{\prime} \beta_{k}\right), \quad k=2, \ldots, 4,
$$

\footnotetext{
${ }^{16}$ We opted for a multinomial logistic model rather than for a multinomial probit as the latter is not adequate to model events whose distribution is highly skewed towards one of the possible outcomes, as Table 1 signals to be the case for the data at hand.
} 
The partial derivative of Eq. (4) with respect to $\mathrm{x}_{1}$ gives us the interaction effect of these two variables upon the odds ratio of opting for the $k$-th destination over staying in Ecuador:

$$
\frac{\partial^{2} \frac{p_{j k}}{p_{j 1}}}{\partial x_{1 j} \partial x_{2 j}}=\left[\beta_{12 k}+\left(\beta_{1 k}+\beta_{12 k} x_{2 j}\right)\left(\beta_{2 k}+\beta_{12 k} x_{1 j}\right)\right] \exp \left(\mathbf{x}_{j}^{\prime} \beta_{k}\right), k=2, \ldots, 4 .
$$

If Eq. (5) is negative, then an increase in migration networks increases the an increase in the size of networks increases the relative probability of migration for an individual with low schooling vis-à-vis an individual with a high level of schooling. The statistical significance of the point estimate of the interaction effect, which needs not to coincide with the one of the coefficient of the interacted variable $x_{12}$, can be obtained through the application of the Delta method that allows deriving the standard error of Eq. (5) (AI and NORTON, 2003). ${ }^{17}$ The interaction effect described in Eq. (5) allows us to identify how the pattern of migrants' self-selection with respect to education changes according with the variation in the size of migration networks across counties. Our central interest resides in assessing how networks which are defined with respect to pre-crisis migration episodes to the United States only influence the pattern of migrants' self-selection to the United States.

\section{THREATS TO IDENTIFICATION}

Before turning to the estimation of the multinomial logistic model outlined in Eq. (2), we need to analyze some factors which could produce observable implications that are closely related to the ones that would be generated by the relationship between the size of migration networks and the pattern of self-selection that we want to test.

The first of the four factors that can pose a threat to our identification strategy is represented by the undercounting of the migrants in the ENEMDU 2005 discussed in section $4 .{ }^{18} \mathrm{~A}$ dimension of the undercounting is represented by whole household migration. As far as the United States are concerned, whole household migration in the aftermath of the crisis occurred mostly through the family reunification provisions that earlier migrants could activate, while it is unlikely that the whole households opted for migration through illegal routes, because of the high monetary costs - and the associated risks - connected to such a choice. This reasoning entails that the scope for whole household migration in the post-crisis period was greater in counties with larger migration networks. This poses a threat to our identification strategy if migrants belonging to whole households that move have a higher level of schooling than the

\footnotetext{
17 The statistical significance of the interaction effect is - as it happens for all marginal effects in non linear models specific for each observation.

18 The empirical evidence on migrants' selection can be sensitive to such an undercounting, as shown by FERNÁNDEZ-HUERTAS MORAGA (2008a).
} 
rest of the migrants, as the inability to record whole household migration would induce a downward bias in the observed level of schooling of the migrants from counties with a previous record of international migration.

Along the same lines, it can be plausibly argued that interviewees might be less reluctant to disclose information about a migrant member who holds a legal residence permit at destination, and - as far as the United States are concerned - the share of legal migrants is likely to be higher out of counties with larger migration networks. If illegal migrants are less educated than those who moved through legal routes, then the average level of education observed in the ENEMDU 2005 for the migrants from counties with a limited size of migration networks would be higher than the actual one, and this would introduce a spurious negative relationship between migrants' education and networks.

If the undercounting due to whole household and illegal migration does represent a threat to identification, then these two forms of migration exert opposite - and possibly offsetting effects on the level of schooling of the migrants recorded in the ENEMDU 2005. This entails that we cannot gauge the relevance of this possible threat to identification comparing the figures on the education of the migrants from the ENEMDU 2005 with figures based on surveys conducted in destination countries. Conversely, more can be learnt directly from the analysis of the destination country data sources, specifically from the 2005-2008 rounds of the ACS and from the ENI 2007.

Ecuadorian migrants can be divided into three mutually exclusive groups: legal migrants who belong to whole households that moved, legal migrants who do not belong to whole households that moved, and illegal migrants. Not surprisingly, neither of the two surveys poses a question concerning the legal status of the respondents, nor it is possible to identify migrants who moved with their whole household, but we can nevertheless get a sense of the size of the three groups for both destinations from other sources.

For the United States, the Yearbook of Immigration Statistics reveals that 21,249 Ecuadorians become legal permanent residents in the country between 1998 and 2001 (UNITED STATES, DEPARTMENT OF HOMELAND SECURITY); ${ }^{19}$ over the same period, the 2005 to 2008 rounds of the ACS report 58,923-66,919 new Ecuadorian immigrants, and the comparison of the two figures is consistent with the estimate of illegal migrant flows by HOEFER, RYTINA and BAKER [2008]. Hence, we can say that roughly two out of three Ecuadorians who entered the United States in the post-crisis period did so through illegal routes. With respect to the size of whole household migration, we can follow MCKENZIE and RAPOPORT [2007a], relying on the marital status of the migrants as a proxy for whole household migration. Specifically, MCKENZIE and RAPOPORT [2007a] assume that a migrant who is married and with the spouse present belongs to a whole household that moved, and we depart slightly from their approach by imposing a further condition to identify this group of migrants: namely, that the spouse was also born in

\footnotetext{
${ }^{19}$ This figure refers to new arrivals only; disaggregated data for later years are not available.
} 
Ecuador. ${ }^{20}$ Applying this proxy for whole household migration, we have that an estimated 13,021-17,185 Ecuadorians who entered the United States between 1998 and 2001 moved with their whole household. ${ }^{21}$ By difference, the size of the group of the other legal migrants ranges roughly between 4,000 and 8,000 .

In the ACS 2005-2008, we can single out migrants who belong to whole households that moved from the other two groups of Ecuadorian migrants, and test whether the level of schooling of the first group is significantly higher than the average level of the rest of the migrants. Focusing on the 2,272 Ecuadorians who migrated between 1998 and 2005 and were aged $19-49$ at the time of migration, the average level of schooling for the first group stands at 11.8 years, while the corresponding figure for the other migrants is 11.2 years. The difference between the two figures is statistically significant, but it can be related to differences in observables - such as age and gender - between the individuals in the two groups: once we control for these two variables, the difference in education that can be attributed to whole household migration stands at 0.4 years, and the null that the true difference is zero can be rejected only at the 10 percent confidence level.

The ACS does not allow to separately identify the group of illegal migrants, but we can now resort to a comparison between the ACS 2005-2008 and the ENEMDU 2005.22 The observed level of schooling of the migrants in the latter survey blends the average level of schooling of legal migrants who do not belong to whole households that moved and of illegal migrants, and this second group is likely to be underrepresented given the greater reluctance of the respondents to disclose information about them. This entails that the average level of schooling of the migrants to the United States observed in the ENEMDU 2005, which stands at 10.1 years as reported in Table 1, should be higher than the one observed years from the ACS 2005-2008 if legal migrants are better educated than illegal ones. Still, the latter is equal to 11.2 years, and the difference between the two surveys is not significant. ${ }^{23}$

With respect to the other main destination, the recurrent regularizations that Spain adopted over our reference period suggest that the legal status of the migrants is unlikely to pose a threat to identification, as just a small share of Ecuadorians did not have a legal residence permit in December 2005, when the Ecuadorian survey was conducted (BERTOLI, FERNÁNDEZ-Huertas Moraga and ORTEga, 2010). Still, whole household migration could be driving a wedge between the actual level of schooling of Ecuadorian migrants to Spain, and the one that we observe in the ENEMDU 2005. The ENI 2007 includes 958 Ecuadorians who

\footnotetext{
20 This latter restriction has been introduced to avoid incorrectly regarding migrants who got married in the United States with a non-Ecuadorian as belonging to whole households that move.

${ }^{21} 22.6$ and 36.1 percent of male migrants to the United States and Spain are married and with their spouse present, while the corresponding figures for female migrants stand at 35.3 and 34.7 percent.

22 The ACS provides no information on the county or province of origin of Ecuadorian immigrants.

${ }^{23}$ The educational attainment of the migrants in the ACS 2005-2008 is measured at the time of the survey, so that the migrants might have acquired additional years of schooling at destination; if we restrict the sample to 2,036 Ecuadorians who were not attending school at the time of the survey - which only partly addresses this issue - the average years of education for migrants belonging to whole household falls from 11.2 to 10.9 years.
} 
migrated between 1998 and 2005 and who were aged 19-49 at that time: adopting the same proxy for whole household migration that we used for the ACS data, we see that migrants belonging to whole households that moved have on average 10.4 years of schooling, while the rest of the migrants have 10.8 years, with the difference between the two figures being not significant at conventional confidence levels. ${ }^{24}$ Furthermore, neither of the two figures is significantly different from the 11.2 years observed in the ENEMDU 2005.

This is reassuring for our identification strategy, as the undercounting of the migrants does not pose a threat to identification provided that there are not significant differences in the average level of education of the Ecuadorians who moved to the United States in the aftermath of the crisis through different routes. ${ }^{25}$ This can be probably related to the extremely high monetary cost of migrating illegally to the United States, as the ability to afford this cost was likely to be positively correlated with the level of education of a would-be migrant. Nevertheless, to fully address the challenge posed by whole household migration, we adopt the methodology proposed by MCKENZIE and RAPOPORT [2007a]. Specifically, we compute the share of migrants who are likely to belong to whole households that moved for every set of migrants identified by the combination of destination, gender and education. ${ }^{26}$ Then, we inflate the sampling weights of the migrants in the ENEMDU 2005 accordingly, and re-estimate our multinomial logistic model with the adjusted weights that correct for the unobservability of whole households that move. ${ }^{27}$

The second threat to our identification strategy is posed by the effect exerted by possible factors that contributed to the creation of pre-crisis networks and that influenced the decision to migrate in the aftermath of the crisis. These factors, such as poor local employment opportunities, could introduce a spurious relationship between the size of migration network and the probability to migrate in our reference period. The econometric analysis addresses this concern by allowing for location-specific shocks - at the province or at the county level - in the probability to migrate, and it also includes additional province- and county-level controls drawn from other secondary data sources. Still, such an econometric specification allows for differences in the probability to migrate across counties, but it does not allow for shocks that

\footnotetext{
24 The ENI 2007 provides information on the province of origin of Ecuadorian immigrants, so that we can control for this information when testing whether migrants who moved with their whole households are better educated than the others; the difference in the average level of schooling remains non signifcant also in this case, suggesting that composition effects are not driving the evidence obtained on country-wide figures.

25 A remaining concern is that also destination country data sources could be undercounting illegal Ecuadorian migrants, as CHIQUIAR and HANSON [2005] argue for Mexicans; still, the problem is likely to be more severe for recently arrived immigrants (HANSON, 2006), and our use of later rounds of the ACS can partly address this concern: the size of Ecuadorian migration to the United States over 1998-2005 indeed increases from 125,000 (ACS 2005) to 154,000 (ACS 2008), and the evidence presented in the paper does not change when we use the ACS 2007 or 2008 alone.

${ }^{26}$ We distinguish among three levels of education: college graduates, non college graduates with some education and no education.

27 This approach assumes no correlation between the incidence of whole household migration and the size of networks: an additional robustness check would be represented by conversely assuming a positive correlation between the two, but we do not perform this additional test given the limited evidence of a significant difference in the level of education between the migrants who moved with their whole households and the others.
} 
are specific with respect to both the county and the level of education; ${ }^{28}$ a spurious negative relationship between migration networks and the pattern of self-selection could arise if networks happened to be larger in the counties where a negative migrants' self-selection would have been anyway more likely. Luckily, the variety of destinations chosen by Ecuadorian migrants in the aftermath of the crisis offers a chance to assess the relevance of this concern with the estimation of the multinomial logistic model itself. If the size of migration networks correlates with unobserved county-specific factors that induce a negative selection of the migrants in education, then the interaction between the years of schooling and networks should exert a significant influence also upon the odds ratio of opting for Spain or the Rest of the World versus staying in Ecuador, though networks are defined with respect to migration episodes to the United States only. If networks do not significantly influence the pattern of selection towards other destinations, then this would help to dismiss the concern relating to the impact of unobserved county-specific factors which might influence the pattern of selection of the migrants to the United States.

A third threat to our estimation approach relates to the fact that Ecuadorian migrants opted for multiple possible destinations in the aftermath of the crisis, as there might be destination-specific out-selection factors - such as immigration policies - that could introduce a spurious negative relationship between migration networks and the pattern of self-selection with respect to education of the migrants to the United States. Specifically, we need to understand whether a negative relationship between networks and the level of schooling of the migrants to the United States could be generated by the the immigration policies and the structure of wages in Spain, rather than by the influence exerted by networks upon migration costs across different levels of schooling.

Imagine that migration networks do reduce moving costs, but that the intensity of the reduction - contrary to what both MCKENZIE and RAPOPORT [2007a] and BEINE, DocQUIER and ÖZDEN [2009] assume - is invariant across levels of schooling, and that migrants out of the Ecuadorian counties with limited to non-existent pre-crisis networks are positively self-selected to the United States, while low-educated migrants opt for Spain. If the cost-reducing effect of networks suffices to induce would-be migrants out of counties with large-sized networks to opt for the United States irrespectively of their level of schooling, then the average level of education of the migrants to the United States from these counties would be lower than from the rest of Ecuador. In this case, the relationship between migration networks and the pattern of self-selection of the migrants to the United States might appear to be driven by the influence exerted by Spain upon the sorting of Ecuadorian migrants across destinations.

But, if this relationship is spurious, then we should be able to argue that it could take an opposite sign if Spain - through its immigration policy and wage structure - was to attract

\footnotetext{
28 MCKenZiE and RAPOPORT [2007a] and BeINE, DocQuiER and ÖzDEN [2009] address this concern through an instrumental variable approach, which is unfeasible for the case at hand due to the lack of adequate instruments for migration networks.
} 
Ecuadorians with a high level of schooling. As before, because of the cost-reducing effect of networks, migrants out of counties with a long-standing record of international migration would still be heading towards the United States, and the relationship between the size of networks and the pattern of self-selection would be positive if low-educated migrants out of counties with limited migration networks opted for the United States. But such an outcome is at best - highly implausible, as it is based on the unwarranted assumption that the set of main destinations for Ecuadorian migrants would remain unchanged in the face of relevant immigration policy changes.

The monthly inflows of Ecuadorians to Spain according to the Pádron, Local Population Registry, collapsed since August 2003, when the visa waiver that had been granted to Ecuadorians in 1963 was cancelled (Bertoli, Fernández-Huertas Moraga and OrTega, 2010), and no corresponding increase in the inflows to the United States emerges from the ACS: the ACS 2008 reveals that yearly inflows to the United States averaged at 15,300 over the 2004-2006 period, compared to 19,400 in 2003. This suggests that, though out-selection factors shape migrants' self-selection (BEINE, DOCQUIER and ÖZDEN, 2009), an increase in pre-crisis migration networks would have pushed towards a negative selection of the migrants to the United States even in the presence of a different immigration policy stance in Spain. Clearly, the evidence that we provide - as the one put forward by MCKENZIE and RAPOPORT [2007a] - is conditional on the immigration policy adopted by the United States, as networks can interfere with the pattern of self-selection in education only if assimilation and policy-induced migration costs are sizeable, as it was indeed the case in the aftermath of the Ecuadorian crisis.

A fourth concern is represented by the endogeneity of educational choices with respect to the decision to migrate, as the literature on the so called beneficial brain drain evidences (MOUNTFORD, 1997; VIDAL, 1998; BEINE, DOCQUIER and RAPOPORT, 2001, 2008). Individuals from counties with larger migration networks could have adapted their educational decisions to their better chances to migrate to the United States; BERTOLI, FERNÁNDEZ-HUERTAS MORAGA and ORTEGA [2009] evidence that the wage differential between the United States and Ecuador is larger for college graduates. This entails that a better access to migration networks could have provided additional incentives to invest in education; though we cannot control for this as MCKENZIE and RAPOPORT [2007a] do as there is no estimate of the impact on the prospect to migrate upon human capital formation in Ecuador, ${ }^{29}$ this factor goes against finding the hypothesized negative relationship between migration networks and the level of schooling of the migrants.

\footnotetext{
${ }^{29}$ CAlero, Bedi and Sparrow [2009] provide evidence of a positive impact of remittances upon school attendance in Ecuador.
} 


\section{Estimates}

The vector of regressors that is used to estimate the multinomial logistic model in Eq. [2] includes individual-level (gender, age, marital status, years of education), household-level (residence in rural areas, indigenous self-identification, number of working age members, pre-crisis migration experience), ${ }^{30}$ county-level (migration networks, extent of bank failures) and province-level variables (income per capita and a proxy for the schooling infrastructure) ${ }^{31}$. As described in section 6, we also include an interaction term between the years of education and migration networks, and we will focus on the size and significance of the interaction effect between the two variables on the relative probability of moving to the United States versus staying in Ecuador.

The first three data columns in Table 2 report the results from the estimation of the multinomial logistic model without the interaction term, while the last three data columns report the estimates from a specification which includes the interacted variable. These two specifications show that Ecuadorian migrants to the United States are more likely to be male, married and to come from rural areas than stayers in Ecuador. Similarly, belonging to a household with a pre-1998 migration experience or with a larger number of working age members increases the odds ratio of moving to the United States versus staying in Ecuador, while the indigenous self-identification reduces this odds ratio.

The estimates from the two specifications also reveal that gender does not systematically vary between stayers and Ecuadorian migrants to Spain, who are also more likely to be married and to come from households with a pre-1998 migration experience and with a larger number of working age members. The relationship between age and the odds ratio of moving to Spain versus staying in Ecuador follows a hump-shaped pattern. Interestingly, the extent of the adverse shock induced by the bank failures increases the odds ratio of moving to the three possible destinations, but it is only marginally significant for just one regression. The lack of statistical significance can be probably attributed to the two opposite effects induced by the exposure to the consequences of a bank failure: while the negative wealth effect can be reasonably expected to increase the incentives to migrate, the lack of access to financial savings limits a would-be migrant's ability to cover the monetary migration costs. The odds ratio of migrating to each of the two main destinations versus staying in Ecuador is increasing with the level of per capita income and the proxy for the schooling infrastructure.

\footnotetext{
${ }^{30}$ The asset index has not been included due to the concerns about its endogeneity with respect to migration.

31 The first province-level variable is gross domestic product - excluding the oil sector - per capita at the province level for 2001 (Banco Central del Ecuador, Cuentas Provinciales), while the second in the number of pupils per teacher (Ministry of Education), so that a higher value of the variable is associated with a poorer school infrastructure.
} 
TABle 2.

Estimates of the multinomial logistic model

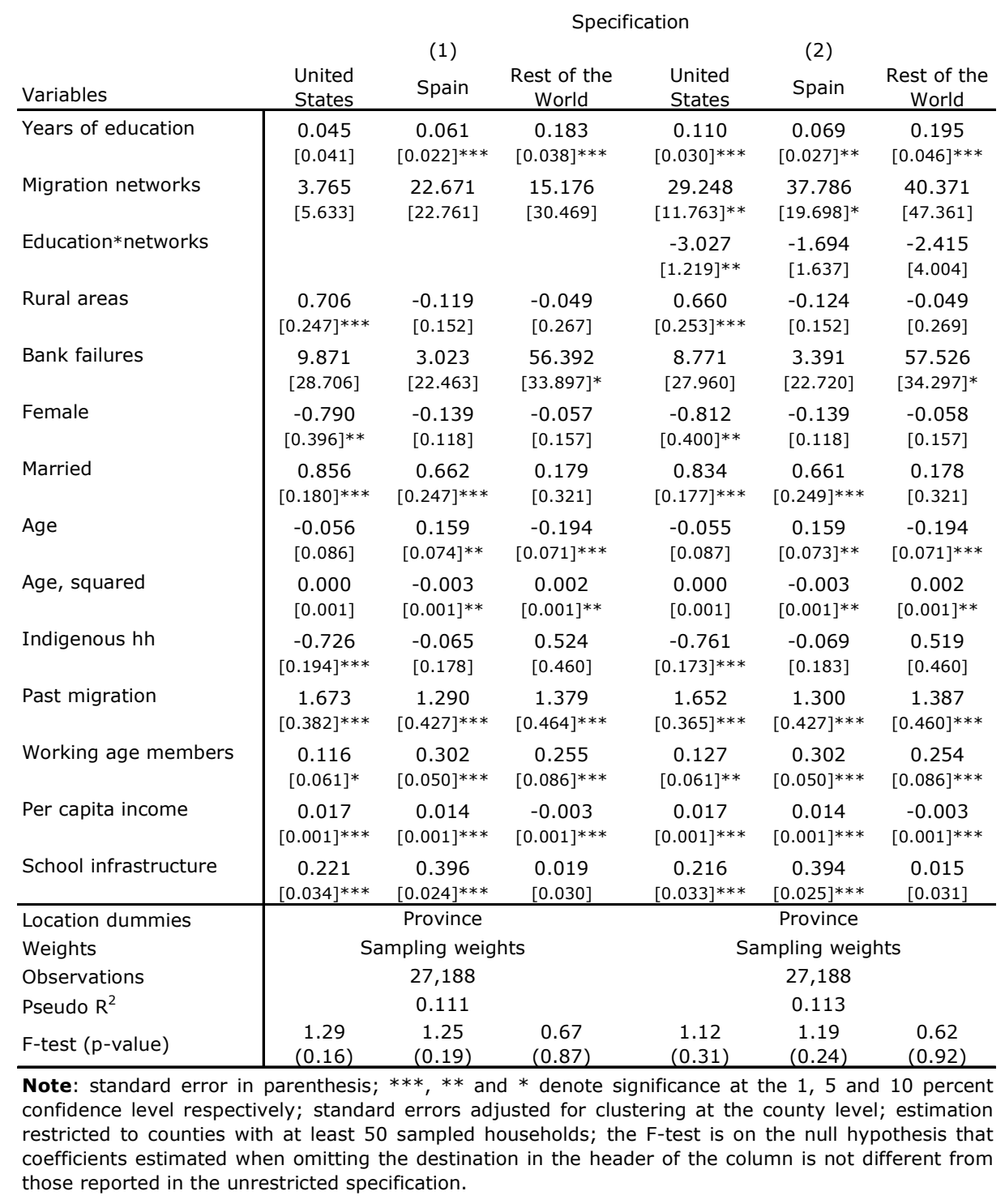

The number of years of education increases the three odds ratios, and it is always highly statistically significant but in the first regression of the first specification. This would seem to suggest that schooling does not influence the choice of moving to the United States versus staying in Ecuador, but such a conclusion would be misplaced, as it is due to the omission of the interaction term which captures the influence exerted by networks upon the patterns of self-selection with respect to schooling. The coefficient of the number of years of education becomes statistically significant also in the first regression once the interaction term between the years of education and migration networks is included. The estimates in the second specification in Table 2 entail that a variation in the years of schooling produces a positive impact on the relative probabilities of opting for one of the two main destinations when the size of migration networks is equal to the country average of 1 percent: Eq. (4) reveals that the marginal effect of the years of education is equal to 0.081 and 0.053 times the respective 
odds ratio for the United States and Spain. ${ }^{32}$ The last three data columns of Table 2 also display the expected positive coefficient for migration networks for the three destinations, though with different levels of significance. Besides the impact on the scale of migration flows, the estimation of the second specification of the model suggests that migration networks have a significant role in explaining the pattern of self-selection of Ecuadorian migrants to the United States. The sign and significance of the coefficient of the interacted variable are not informative - as argued by AI and NORTON [2003] - about the size and significance of the interaction effect between networks and education: the former is computed according to Eq. (5), while the second is assessed with a Wald test once the standard error is recovered through the application of the Delta method.

FIGURE 4.

Interaction effect of education and migration networks

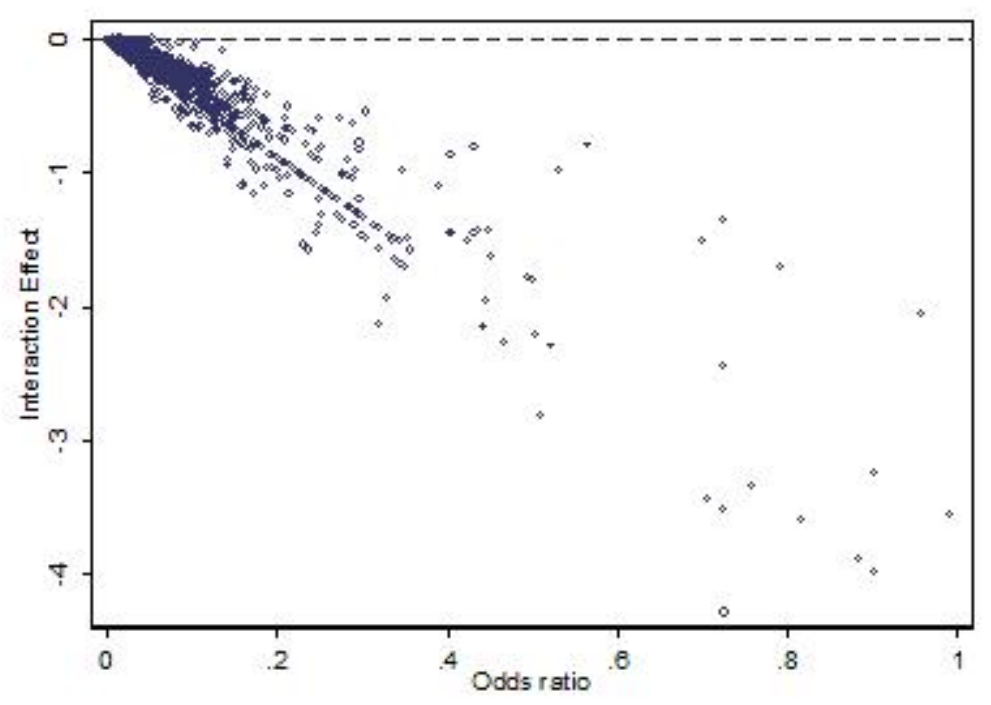

Figure 4 plots the interaction effect against the odds ratio of migrating to the United States versus staying in Ecuador. The interaction effect is negative for all but 696 observations: ${ }^{33}$ this entails that an increase in the size of migration networks drives down the marginal effect of an increase in the years of education upon the odds ratio, which can be either positive or negative to begin with. Figure 5 reports the Wald test statistic against the estimated odds ratio: the null hypothesis that the interaction effect is equal to 0 is rejected at 5 and 10 percent confidence level for 1,751 and 5,610 observations respectively.

\footnotetext{
32 The estimated coefficients in the fourth data column in Table 2 imply that the marginal effect of education upon the relative probability of migrating to the United States becomes negative when the proposed measure of the size of migration networks exceeds 3.6 percent.

${ }^{33}$ From a simple inspection of Eq. (4), we can observe that the point estimates reported in Table 2 for $\beta_{12}, \beta_{1}$, and $\beta_{2}$ entail that the interaction effect is positive when both the interacted variables are close to zero, i.e. for individuals with little education coming from counties with no migration networks.
} 
FIGURE 5.

Wald test of the significance of the interaction effect

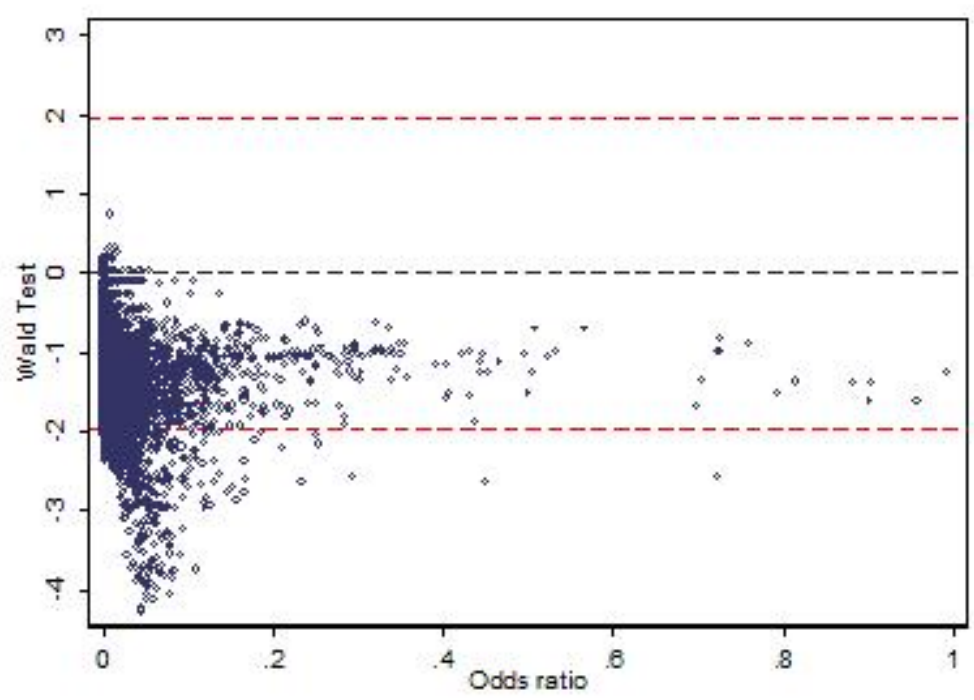

We can focus on the two provinces, Azuay and Cañar, with a long-standing record of migration to the United States to gauge the relevance - besides its statistical significance - of the influence exerted by networks on the aggregate pattern of self-selection in education. The migrants to the United States from Azuay and Cañar have, on average, 7.8 years of schooling, compared to 12.2 for the migrants from the rest of Ecuador. We can draw the estimated coefficients in the second specification in Table 2 to compute - according to Eq. (3) - the relative probability of migrating to the United States for the individuals from Azuay and Cañar in a hypothetical scenario where the counties in these two provinces had been characterized by the same size of networks as the rest of the country. Then, we can use the estimated individual relative probabilities of migration to compute the average level of schooling of migrants to the United States: this stands at 9.7 years, so that the difference in the size of pre-crisis networks accounts for 43 percent of the observed difference in the level of schooling for the migrants to the United States from Azuay and Cañar. ${ }^{34}$

As discussed in section 7, the estimated impact of networks might be capturing county-specific unobserved factors that shape the pattern of self-selection with respect to education, but that - if the observed effect is indeed spurious - networks should also negatively influence the pattern of selection of the migrants towards the other destinations. But this hypothesis is not validated by the data: the interaction effect between networks and years of education on the odds ratio of going to Spain versus staying in Ecuador is positive for 9,001 observations, and it is not significant for all the observations in the sample. Similarly, the interaction effect on the odds ratio of going to any other destination versus not migrating is positive for 15,364 observations, and it is significantly negative just for 2 observations. These estimates help to considerably soften the concern due to possible unobserved factors shaping migrants' self-selection which could correlate with the size of pre-crisis networks.

\footnotetext{
${ }^{34}$ This exercise generates only negligible changes in the estimated average level of schooling of the stayers.
} 
The last data row in Table 2 reports the F-test statistic obtained when testing, for each specification, the null hypothesis that the coefficients reported in the Table are identical to those obtained when re-estimating the model by dropping one of the destinations. Specifically, the 1.29 statistic for the first specification refers to a restricted version of the model where we have dropped migrants to the United States. The null hypothesis is not rejected at conventional confidence level, and this is consistent with the assumption concerning the structure of the error term.

Table 3 reports the estimates for additional specifications of the model in Eq. (2); specifically, in the first three data columns, we report the estimated coefficients obtained when omitting the variable that describes whether an individual belongs to a household with a migration experience in the pre-crisis period, as this variable might be capturing not only a closer access to networks, but also some unobserved household characteristics, such as linguistic skills or attitude towards risk. The point estimates of the coefficients that determine the size of the interaction effect in Eq. (5) are almost unaffected, and the last data row in Table 3 signals that there are 1,143 observations for which the interaction effect is negative and significant at the 5 percent confidence level.

The second and the third specification in Table 3 introduce a more flexible pattern of selection with respect to education, by allowing the relationship between the years of schooling and the probability to migrate to be non-monotonic, and to differ between urban and rural areas. Neither of the two additional specifications produces influences the estimated relationship between the pattern of migrants' self-selection to the United States and the size of migration networks, but they are better able to describe how the relative probability of migrating to Spain evolves with the level of schooling. The second specification suggests that the relationship between the relative probability of migrating to Spain and education follows a hump-shaped pattern, which peaks at around 12.7 years of schooling, ${ }^{35}$ while the third specification evidences that the this pattern characterizes urban areas only, as in rural areas the marginal effect of schooling remains positive throughout the range of schooling levels.

\footnotetext{
35 This finding helps to reconcile the analysis with Bertoli, Fernández-Huertas Moraga and OrTega (2010), who find that - using the ENI 2007 and ACS 2007 surveys for migrants, and college degree as the measure of educational attainnment - Ecuadorian migrants to Spain are negatively self-selected in education.
} 
TABLE 3.

Additional specifications of the multinomial logistic model

\begin{tabular}{|c|c|c|c|c|c|c|c|c|c|}
\hline \multirow[b]{3}{*}{ Variables } & \multicolumn{9}{|c|}{ Specification } \\
\hline & \multicolumn{3}{|c|}{ (1) } & \multicolumn{3}{|c|}{ (2) } & \multicolumn{3}{|c|}{ (3) } \\
\hline & $\begin{array}{l}\text { United } \\
\text { States }\end{array}$ & Spain & $\begin{array}{c}\text { Rest of the } \\
\text { World }\end{array}$ & $\begin{array}{l}\text { United } \\
\text { States }\end{array}$ & Spain & $\begin{array}{c}\text { Rest of the } \\
\text { World }\end{array}$ & $\begin{array}{l}\text { United } \\
\text { States }\end{array}$ & Spain & $\begin{array}{l}\text { Rest of the } \\
\text { World }\end{array}$ \\
\hline Years of education & $\begin{array}{c}0.113 \\
{[0.031]^{* * *}}\end{array}$ & $\begin{array}{c}0.071 \\
{[0.027]^{* * *}}\end{array}$ & $\begin{array}{c}0.197 \\
{[0.047]^{* * *}}\end{array}$ & $\begin{array}{c}0.171 \\
{[0.092]^{*}}\end{array}$ & $\begin{array}{c}0.483 \\
{[0.118]^{* * *}}\end{array}$ & $\begin{array}{c}0.394 \\
{[0.248]}\end{array}$ & $\begin{array}{c}0.149 \\
{[0.102]}\end{array}$ & $\begin{array}{c}0.402 \\
{[0.116]^{* * *}}\end{array}$ & $\begin{array}{c}0.336 \\
{[0.273]}\end{array}$ \\
\hline Education, squared & & & & $\begin{array}{l}-0.003 \\
{[0.005]}\end{array}$ & $\begin{array}{c}-0.019 \\
{[0.005]^{* * *}}\end{array}$ & $\begin{array}{l}-0.008 \\
{[0.011]}\end{array}$ & $\begin{array}{l}-0.002 \\
{[0.005]}\end{array}$ & $\begin{array}{c}-0.016 \\
{[0.005]^{* * *}}\end{array}$ & $\begin{array}{l}-0.006 \\
{[0.012]}\end{array}$ \\
\hline Education*rural & & & & & & & $\begin{array}{c}0.021 \\
{[0.040]}\end{array}$ & $\begin{array}{c}0.116 \\
{[0.039]^{* * *}}\end{array}$ & $\begin{array}{c}0.078 \\
{[0.073]}\end{array}$ \\
\hline Migration networks & $\begin{array}{c}32.266 \\
{[10.916]^{* * *}}\end{array}$ & $\begin{array}{c}42.054 \\
{[19.467]^{* *}}\end{array}$ & $\begin{array}{c}44.222 \\
{[46.199]}\end{array}$ & $\begin{array}{c}33.395 \\
{[11.098]^{* * *}}\end{array}$ & $\begin{array}{c}47.863 \\
{[22.024]^{* *}}\end{array}$ & $\begin{array}{c}47.486 \\
{[53.121]}\end{array}$ & $\begin{array}{c}33.913 \\
{[10.674]^{* * *}}\end{array}$ & $\begin{array}{c}49.358 \\
{[23.048]^{* *}}\end{array}$ & $\begin{array}{c}47.409 \\
{[59.817]}\end{array}$ \\
\hline Education*networks & $\begin{array}{c}-2.942 \\
{[1.135]^{* * *}}\end{array}$ & $\begin{array}{l}-1.477 \\
{[1.705]}\end{array}$ & $\begin{array}{l}-2.190 \\
{[4.112]}\end{array}$ & $\begin{array}{c}-3.083 \\
{[1.171]^{* * *}}\end{array}$ & $\begin{array}{l}-2.049 \\
{[1.909]}\end{array}$ & $\begin{array}{l}-2.435 \\
{[4.699]}\end{array}$ & $\begin{array}{c}-3.124 \\
{[1.137]^{* * *}}\end{array}$ & $\begin{array}{l}-2.099 \\
{[1.815]}\end{array}$ & $\begin{array}{l}-2.311 \\
{[5.135]}\end{array}$ \\
\hline Rural areas & $\begin{array}{c}0.695 \\
{[0.258]^{* * *}}\end{array}$ & $\begin{array}{l}-0.126 \\
{[0.153]}\end{array}$ & $\begin{array}{l}-0.048 \\
{[0.273]}\end{array}$ & $\begin{array}{c}0.700 \\
{[0.254]^{* * *}}\end{array}$ & $\begin{array}{l}-0.040 \\
{[0.162]}\end{array}$ & $\begin{array}{l}-0.002 \\
{[0.280]}\end{array}$ & $\begin{array}{c}0.508 \\
{[0.447]}\end{array}$ & $\begin{array}{c}-1.184 \\
{[0.401]^{* * *}}\end{array}$ & $\begin{array}{l}-0.874 \\
{[1.008]}\end{array}$ \\
\hline Bank failures & $\begin{array}{c}9.862 \\
{[27.448]}\end{array}$ & $\begin{array}{c}-0.118 \\
{[23.073]}\end{array}$ & $\begin{array}{c}56.719 \\
{[36.640]}\end{array}$ & $\begin{array}{c}9.372 \\
{[27.631]}\end{array}$ & $\begin{array}{c}-0.967 \\
{[22.461]}\end{array}$ & $\begin{array}{c}56.193 \\
{[36.406]}\end{array}$ & $\begin{array}{c}9.033 \\
{[27.912]}\end{array}$ & $\begin{array}{c}-1.714 \\
{[22.156]}\end{array}$ & $\begin{array}{l}55.587 \\
{[36.554]}\end{array}$ \\
\hline Female & $\begin{array}{c}-0.794 \\
{[0.402]^{* *}}\end{array}$ & $\begin{array}{l}-0.140 \\
{[0.118]}\end{array}$ & $\begin{array}{l}-0.057 \\
{[0.157]}\end{array}$ & $\begin{array}{c}-0.791 \\
{[0.399]^{* *}}\end{array}$ & $\begin{array}{l}-0.129 \\
{[0.118]}\end{array}$ & $\begin{array}{l}-0.053 \\
{[0.161]}\end{array}$ & $\begin{array}{c}-0.792 \\
{[0.398]^{* *}}\end{array}$ & $\begin{array}{l}-0.131 \\
{[0.119]}\end{array}$ & $\begin{array}{l}-0.055 \\
{[0.162]}\end{array}$ \\
\hline Married & $\begin{array}{c}0.791 \\
{[0.179]^{* * *}}\end{array}$ & $\begin{array}{c}0.658 \\
{[0.245]^{* * *}}\end{array}$ & $\begin{array}{c}0.170 \\
{[0.323]}\end{array}$ & $\begin{array}{c}0.785 \\
{[0.174]^{* * *}}\end{array}$ & $\begin{array}{c}0.623 \\
{[0.244]^{* *}}\end{array}$ & $\begin{array}{c}0.162 \\
{[0.326]}\end{array}$ & $\begin{array}{c}0.789 \\
{[0.171]^{* * *}}\end{array}$ & $\begin{array}{c}0.627 \\
{[0.237]^{* * *}}\end{array}$ & $\begin{array}{c}0.167 \\
{[0.325]}\end{array}$ \\
\hline Age & $\begin{array}{l}-0.056 \\
{[0.087]}\end{array}$ & $\begin{array}{c}0.162 \\
{[0.074]^{* *}}\end{array}$ & $\begin{array}{c}-0.194 \\
{[0.071]^{* * *}}\end{array}$ & $\begin{array}{l}-0.052 \\
{[0.090]}\end{array}$ & $\begin{array}{c}0.194 \\
{[0.071]^{* * *}}\end{array}$ & $\begin{array}{c}-0.174 \\
{[0.083]^{* *}}\end{array}$ & $\begin{array}{l}-0.052 \\
{[0.090]}\end{array}$ & $\begin{array}{c}0.193 \\
{[0.071]^{* * *}}\end{array}$ & $\begin{array}{c}-0.176 \\
{[0.084]^{* *}}\end{array}$ \\
\hline Age, squared & $\begin{array}{c}0.000 \\
{[0.001]}\end{array}$ & $\begin{array}{c}-0.003 \\
{[0.001]^{* *}}\end{array}$ & $\begin{array}{c}0.002 \\
{[0.001]^{* *}}\end{array}$ & $\begin{array}{c}0.000 \\
{[0.001]}\end{array}$ & $\begin{array}{c}-0.004 \\
{[0.001]^{* * *}}\end{array}$ & $\begin{array}{c}0.002 \\
{[0.001]^{*}}\end{array}$ & $\begin{array}{c}0.000 \\
{[0.001]}\end{array}$ & $\begin{array}{c}-0.004 \\
{[0.001]^{* * *}}\end{array}$ & $\begin{array}{c}0.002 \\
{[0.001]^{*}}\end{array}$ \\
\hline Indigenous hh & $\begin{array}{c}-0.764 \\
{[0.198]^{* * *}}\end{array}$ & $\begin{array}{l}-0.073 \\
{[0.183]}\end{array}$ & $\begin{array}{c}0.515 \\
{[0.467]}\end{array}$ & $\begin{array}{c}-0.754 \\
{[0.197]^{* * *}}\end{array}$ & $\begin{array}{l}-0.013 \\
{[0.191]}\end{array}$ & $\begin{array}{c}0.538 \\
{[0.454]}\end{array}$ & $\begin{array}{c}-0.748 \\
{[0.192]^{* * *}}\end{array}$ & $\begin{array}{l}-0.020 \\
{[0.188]}\end{array}$ & $\begin{array}{c}0.540 \\
{[0.449]}\end{array}$ \\
\hline Working age members & $\begin{array}{c}0.130 \\
{[0.058]^{* *}}\end{array}$ & $\begin{array}{c}0.307 \\
{[0.050]^{* * *}}\end{array}$ & $\begin{array}{c}0.261 \\
{[0.082]^{* * *}}\end{array}$ & $\begin{array}{c}0.130 \\
{[0.058]^{* *}}\end{array}$ & $\begin{array}{c}0.308 \\
{[0.051]^{* * *}}\end{array}$ & $\begin{array}{c}0.262 \\
{[0.082]^{* * *}}\end{array}$ & $\begin{array}{c}0.129 \\
{[0.059]^{* *}}\end{array}$ & $\begin{array}{c}0.304 \\
{[0.051]^{* * *}}\end{array}$ & $\begin{array}{c}0.259 \\
{[0.081]^{* * *}}\end{array}$ \\
\hline Per capita income & $\begin{array}{c}0.017 \\
{[0.001]^{* * *}}\end{array}$ & $\begin{array}{c}0.014 \\
{[0.001]^{* * *}}\end{array}$ & $\begin{array}{c}-0.003 \\
{[0.001]^{* * *}}\end{array}$ & $\begin{array}{c}0.017 \\
{[0.001]^{* * *}}\end{array}$ & $\begin{array}{c}0.014 \\
{[0.001]^{* * *}}\end{array}$ & $\begin{array}{c}-0.003 \\
{[0.001]^{* * *}}\end{array}$ & $\begin{array}{c}0.017 \\
{[0.001]^{* * *}}\end{array}$ & $\begin{array}{c}0.014 \\
{[0.001]^{* * *}}\end{array}$ & $\begin{array}{c}-0.004 \\
{[0.001]^{* * *}}\end{array}$ \\
\hline School infrastructure & $\begin{array}{c}0.218 \\
{[0.033]^{* * *}}\end{array}$ & $\begin{array}{c}0.397 \\
{[0.025]^{* * *}} \\
\end{array}$ & $\begin{array}{c}0.019 \\
{[0.032]}\end{array}$ & $\begin{array}{c}0.218 \\
{[0.035]^{* * *}}\end{array}$ & $\begin{array}{c}0.397 \\
{[0.024]^{* * *}}\end{array}$ & $\begin{array}{c}0.019 \\
{[0.032]}\end{array}$ & $\begin{array}{c}0.218 \\
{[0.035]^{* * *}}\end{array}$ & $\begin{array}{c}0.396 \\
{[0.024]^{* * *}}\end{array}$ & $\begin{array}{r}0.018 \\
{[0.032]} \\
\end{array}$ \\
\hline $\begin{array}{l}\text { Location dummies } \\
\text { Weights } \\
\text { Observations } \\
\text { Pseudo } \mathrm{R}^{2}\end{array}$ & $\mathrm{Sa}$ & $\begin{array}{c}\text { Province } \\
\text { mpling weig } \\
27,188 \\
0.108\end{array}$ & & $\mathrm{Sa}$ & $\begin{array}{c}\text { Province } \\
\text { mpling weig } \\
27,188 \\
0.114\end{array}$ & & 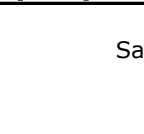 & $\begin{array}{c}\text { Province } \\
\text { mpling weig } \\
27,188 \\
0.115\end{array}$ & \\
\hline F-test ( $p$-value) & $\begin{array}{c}1.11 \\
(0.33)\end{array}$ & $\begin{array}{c}1.53 \\
(0.05)\end{array}$ & $\begin{array}{l}0.91 \\
(0.58)\end{array}$ & $\begin{array}{l}1.05 \\
(0.40)\end{array}$ & $\begin{array}{c}1.34 \\
(0.12)\end{array}$ & $\begin{array}{c}0.77 \\
(0.78)\end{array}$ & $\begin{array}{c}1.02 \\
(0.43)\end{array}$ & $\begin{array}{l}1.15 \\
(0.27)\end{array}$ & $\begin{array}{c}0.72 \\
(0.85)\end{array}$ \\
\hline $\begin{array}{l}\text { Int. effect, obs. with } \\
\text { significant Wald Test }\end{array}$ & & 1,143 & & & 1,400 & & & 1,195 & \\
\hline
\end{tabular}

Note: standard error in parenthesis; $* * *, * *$ and $*$ denote significance at the 1,5 and 10 percent confidence level respectively; standard errors adjusted for clustering at the county level; estimation restricted to counties with at least 50 sampled households; the F-test is on the null hypothesis that coefficients estimated when omitting the destination in the header of the column is not different from those reported in the unrestricted specification; the number of observations for which the interaction effect is significant at the 5 percent confidence level is reported.

Table 4 provides further robustness checks on the relationship of interest. The first specification allows for county-level fixed effect, following MCKENZIE and RAPOPORT [2007a], so that the interaction effect between education and networks in Eq. (5) is not identified out of intra-province variability in the size of migration networks. This specification - where networks are dropped as they vary at the county-level - evidences that the interaction effect remains negative and significant for an even larger subset of observations than our baseline 
specification in Table 2: the null hypothesis that the interaction effect is equal to zero is rejected at the 5 percent confidence level for 7,972 observations. ${ }^{36}$

TABLE 4.

Additional specifications of the multinomial logistic model

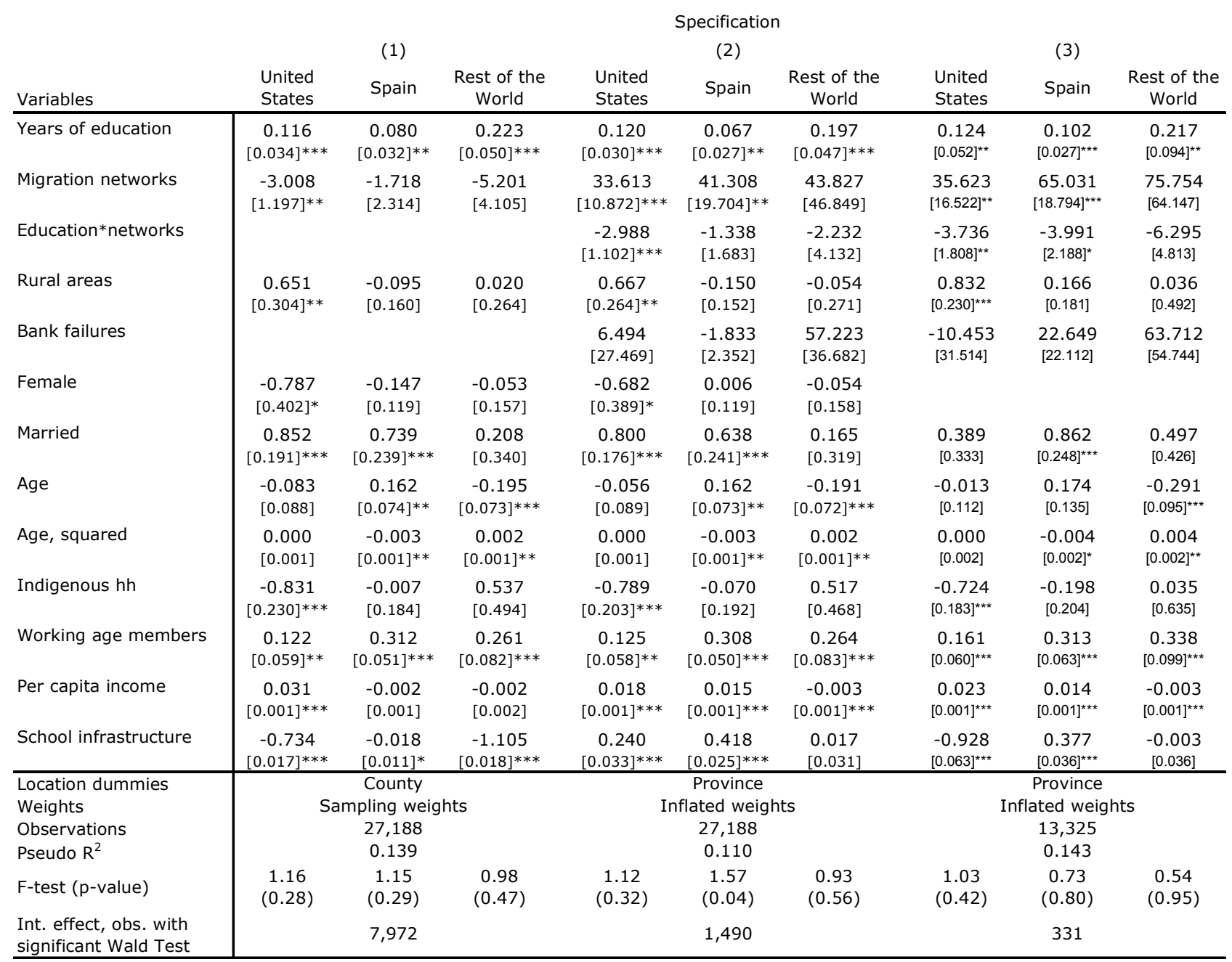

Note: standard error in parenthesis; $* * *, * *$ and $*$ denote significance at the 1,5 and 10 percent confidence level respectively; standard errors adjusted for clustering at the county level; estimation restricted to counties with at least 50 sampled households; the F-test is on the null hypothesis that coefficients estimated when omitting the destination in the header of the column is not different from those reported in the unrestricted specification; the number of observations for which the interaction effect is significant at the 5 percent confidence level is reported.

The second specification applies the methodology adopted in MCKENZIE and RAPOPORT [2007a] to correct for the inability of the ENEMDU 2005 to capture migrants who moved with their whole households. The estimates are robust to inflating sampling weights for migrants in the United States and Spain according to the size of the undercounting of the Ecuadorian migrants suggested by the ACS 2005-2008 and ENI 2007; the F-test statistic suggests that the estimated coefficients do not significantly change when we drop migrants to the Rest of the World, for whom such an adjustment is not possible due to obvious data constraints. As the undercounting due to whole household migration to the United States is more severe for

\footnotetext{
36 The larger subset of observations for which the interaction effect is significant is probably due to the greater precision, due to the inclusion of county dummies, in the estimation odds ratio, which - as shown in Eq. (5) influences the size and significance of the interaction effect.
} 
females, we also re-estimated the model with inflated weights on the subsample of male individuals only. The interaction effect between migration networks and years of education is significant at the 5 percent level for 331 males.

Table 5 reports three additional specifications of the multinomial logistic model to provide further robustness check upon the relationship between migration networks and the pattern of self-selection in education. These three specifications respond to the same underlying motivation: the theoretical predictions upon the role of migration networks are not conditional upon any specific pattern of self-selection with respect to education, so that we re-estimate the model upon different geographical samples where different patterns of education might prevail.

The first specification is restricted to the provinces in the Andean region of the country, which present geo-climatic factors which are similar to the ones in Azuay and Cañar, the two provinces with the largest pre-crisis networks. The estimated coefficient of the years of schooling is not significant in the regression that refers to the United States, but networks still significantly interact with education in shaping the probability to migrate to this destination.

The second specification is estimated on a sample that excludes stayers and migrants from the provinces of Azuay and Cañar. Once again, the estimated interaction effect remains negative and significant for 650 observations, and this specification also further helps to dismiss the concern that our results are driven by unobserved county-specific factors that correlate with the size of migration networks. Dropping the provinces with the strongest record of migration to the United States in the pre-crisis period does not modify the relationship between migration networks and the pattern of self-selection in education of the Ecuadorians who opted for this destination. ${ }^{37}$ The third specification in Table 5 is estimated on a sample which is limited to counties with no more than 100,000 inhabitants, since MCKENZIE and RAPOPORT [2007a] argue that "the role of networks is likely to be greater outside of large cities". The interaction effect remains negative also in this instance.

\footnotetext{
37 The estimation on the set of stayers and migrants from the provinces of Azuay and Cañar alone is not feasible because of the small number of counties in these two provinces, which does not provide us with enough variability in the size of migration networks, which are measured at the county level.
} 
TABLE 5.

Alternative geographical restrictions on the sample

\begin{tabular}{|c|c|c|c|c|c|c|c|c|c|}
\hline \multirow[b]{3}{*}{ Variables } & \multicolumn{9}{|c|}{ Specification } \\
\hline & \multicolumn{3}{|c|}{ (1) } & \multicolumn{3}{|c|}{ (2) } & \multicolumn{3}{|c|}{ (3) } \\
\hline & $\begin{array}{l}\text { United } \\
\text { States }\end{array}$ & Spain & $\begin{array}{l}\text { Rest of the } \\
\text { World }\end{array}$ & $\begin{array}{l}\text { United } \\
\text { States }\end{array}$ & Spain & $\begin{array}{c}\text { Rest of the } \\
\text { World }\end{array}$ & $\begin{array}{l}\text { United } \\
\text { States }\end{array}$ & Spain & $\begin{array}{l}\text { Rest of the } \\
\text { World }\end{array}$ \\
\hline Years of education & $\begin{array}{c}0.044 \\
{[0.042]}\end{array}$ & $\begin{array}{c}0.035 \\
{[0.027]}\end{array}$ & $\begin{array}{c}0.284 \\
{[0.086]^{* * *}}\end{array}$ & $\begin{array}{c}0.135 \\
{[0.033]^{* * *}}\end{array}$ & $\begin{array}{c}0.065 \\
{[0.032]^{* *}}\end{array}$ & $\begin{array}{c}0.177 \\
{[0.053]^{* * *}}\end{array}$ & $\begin{array}{c}0.161 \\
{[0.046]^{* * *}}\end{array}$ & $\begin{array}{c}0.126 \\
{[0.035]^{* * *}}\end{array}$ & $\begin{array}{c}0.243 \\
{[0.049]^{* * *}}\end{array}$ \\
\hline Migration networks & $\begin{array}{c}22.729 \\
{[9.517]^{* *}}\end{array}$ & $\begin{array}{c}24.953 \\
{[15.213]}\end{array}$ & $\begin{array}{c}89.024 \\
{[44.323]^{* *}}\end{array}$ & $\begin{array}{c}80.896 \\
{[22.818]^{* * *}}\end{array}$ & $\begin{array}{l}44.107 \\
{[31.673]}\end{array}$ & $\begin{array}{l}-17.988 \\
{[62.413]}\end{array}$ & $\begin{array}{l}28.871 \\
{[8.168]^{* * *}}\end{array}$ & $\begin{array}{c}36.408 \\
{[12.765]^{\star \star \star}}\end{array}$ & $\begin{array}{c}-707.278 \\
{[515.082]}\end{array}$ \\
\hline Education*networks & $\begin{array}{c}-1.789 \\
{[0.857]^{* *}}\end{array}$ & $\begin{array}{l}-0.121 \\
{[1.514]}\end{array}$ & $\begin{array}{l}-6.570 \\
{[3.749]^{*}}\end{array}$ & $\begin{array}{l}-1.745 \\
{[2.477]}\end{array}$ & $\begin{array}{c}0.262 \\
{[4.060]}\end{array}$ & $\begin{array}{c}3.728 \\
{[5.014]}\end{array}$ & $\begin{array}{c}-2.517 \\
{[0.572]^{* *}}\end{array}$ & $\begin{array}{c}-2.188 \\
{[1.854]}\end{array}$ & $\begin{array}{c}42.138 \\
{[28.647]}\end{array}$ \\
\hline Rural areas & $\begin{array}{c}0.778 \\
{[0.270]^{* * *}}\end{array}$ & $\begin{array}{l}-0.099 \\
{[0.202]}\end{array}$ & $\begin{array}{l}-0.343 \\
{[0.424]}\end{array}$ & $\begin{array}{l}-0.045 \\
{[0.357]}\end{array}$ & $\begin{array}{l}-0.138 \\
{[0.156]}\end{array}$ & $\begin{array}{l}-0.002 \\
{[0.267]}\end{array}$ & $\begin{array}{l}0.852 \\
{[0.469]^{*}}\end{array}$ & $\begin{array}{c}-0.138 \\
{[0.252]}\end{array}$ & $\begin{array}{l}0.702 \\
{[0.415]^{\star}}\end{array}$ \\
\hline Bank failures & $\begin{array}{c}10.348 \\
{[33.319]}\end{array}$ & $\begin{array}{c}-32.923 \\
{[10.897]^{* * *}}\end{array}$ & $\begin{array}{l}-35.560 \\
{[39.965]}\end{array}$ & $\begin{array}{l}-41.789 \\
{[30.479]}\end{array}$ & $\begin{array}{l}-2.941 \\
{[21.964]}\end{array}$ & $\begin{array}{l}53.910 \\
{[36.497]}\end{array}$ & $\begin{array}{l}23.284 \\
{[39.198]}\end{array}$ & $\begin{array}{c}69.565 \\
{[26.536]^{\star \star *}}\end{array}$ & $\begin{array}{l}155.347 \\
{[29.566]^{\star * *}}\end{array}$ \\
\hline Female & $\begin{array}{c}-1.463 \\
{[0.328]^{* * *}}\end{array}$ & $\begin{array}{c}-0.319 \\
{[0.111]^{* * *}}\end{array}$ & $\begin{array}{c}-0.318 \\
{[0.155]^{* *}}\end{array}$ & $\begin{array}{l}-0.133 \\
{[0.281]}\end{array}$ & $\begin{array}{l}-0.131 \\
{[0.119]}\end{array}$ & $\begin{array}{l}-0.040 \\
{[0.159]}\end{array}$ & $\begin{array}{l}-0.774 \\
{[0.378]^{\star *}}\end{array}$ & $\begin{array}{c}-0.142 \\
{[0.207]}\end{array}$ & $\begin{array}{l}0.016 \\
{[0.359]}\end{array}$ \\
\hline Married & $\begin{array}{c}0.808 \\
{[0.169]^{* * *}}\end{array}$ & $\begin{array}{c}0.794 \\
{[0.380]^{* *}}\end{array}$ & $\begin{array}{c}0.572 \\
{[0.379]}\end{array}$ & $\begin{array}{c}0.552 \\
{[0.221]^{* *}}\end{array}$ & $\begin{array}{c}0.689 \\
{[0.246]^{* * *}}\end{array}$ & $\begin{array}{c}0.154 \\
{[0.332]}\end{array}$ & $\begin{array}{c}1.046 \\
{[0.366]^{\star * *}}\end{array}$ & $\begin{array}{l}0.322 \\
{[0.265]}\end{array}$ & $\begin{array}{l}0.190 \\
{[0.581]}\end{array}$ \\
\hline Age & $\begin{array}{c}0.081 \\
{[0.098]}\end{array}$ & $\begin{array}{c}0.181 \\
{[0.088]^{* *}}\end{array}$ & $\begin{array}{c}-0.269 \\
{[0.109]^{* *}}\end{array}$ & $\begin{array}{l}-0.043 \\
{[0.129]}\end{array}$ & $\begin{array}{c}0.148 \\
{[0.072]^{* *}}\end{array}$ & $\begin{array}{c}-0.180 \\
{[0.071]^{* *}}\end{array}$ & $\begin{array}{l}0.035 \\
{[0.097]}\end{array}$ & $\begin{array}{c}0.324 \\
{[0.109]^{\star \star \star}}\end{array}$ & $\begin{array}{c}-0.166 \\
{[0.148]}\end{array}$ \\
\hline Age, squared & $\begin{array}{c}-0.003 \\
{[0.002]^{*}}\end{array}$ & $\begin{array}{c}-0.004 \\
{[0.002]^{* *}}\end{array}$ & $\begin{array}{c}0.002 \\
{[0.002]}\end{array}$ & $\begin{array}{c}0.000 \\
{[0.002]}\end{array}$ & $\begin{array}{c}-0.003 \\
{[0.001]^{* *}}\end{array}$ & $\begin{array}{c}0.002 \\
{[0.001]^{*}}\end{array}$ & $\begin{array}{c}-0.002 \\
{[0.001]}\end{array}$ & $\begin{array}{l}-0.006 \\
{[0.002]^{\star * \star}}\end{array}$ & $\begin{array}{l}0.002 \\
{[0.002]}\end{array}$ \\
\hline Indigenous hh & $\begin{array}{c}-0.798 \\
{[0.204]^{* * *}}\end{array}$ & $\begin{array}{l}-0.197 \\
{[0.144]}\end{array}$ & $\begin{array}{c}0.757 \\
{[0.492]}\end{array}$ & $\begin{array}{c}-1.259 \\
{[0.553]^{* *}}\end{array}$ & $\begin{array}{l}-0.093 \\
{[0.194]}\end{array}$ & $\begin{array}{c}0.558 \\
{[0.454]}\end{array}$ & $\begin{array}{l}-0.865 \\
{[0.373]^{* *}}\end{array}$ & $\begin{array}{l}-0.640 \\
{[0.330]^{*}}\end{array}$ & $\begin{array}{c}-0.432 \\
{[0.729]}\end{array}$ \\
\hline Working age members & $\begin{array}{c}0.186 \\
{[0.044]^{* * *}}\end{array}$ & $\begin{array}{c}0.362 \\
{[0.076]^{* * *}}\end{array}$ & $\begin{array}{c}0.384 \\
{[0.172]^{* *}}\end{array}$ & $\begin{array}{c}0.063 \\
{[0.087]}\end{array}$ & $\begin{array}{c}0.312 \\
{[0.052]^{* * *}}\end{array}$ & $\begin{array}{c}0.266 \\
{[0.084]^{* * *}}\end{array}$ & $\begin{array}{c}0.225 \\
{[0.077]^{* * *}}\end{array}$ & $\begin{array}{c}0.208 \\
{[0.061]^{\star \star *}}\end{array}$ & $\begin{array}{l}0.122 \\
{[0.125]}\end{array}$ \\
\hline Per capita income & $\begin{array}{c}0.004 \\
{[0.000]^{* * *}}\end{array}$ & $\begin{array}{c}-0.003 \\
{[0.001]^{* * *}}\end{array}$ & $\begin{array}{l}-0.001 \\
{[0.001]}\end{array}$ & $\begin{array}{c}0.015 \\
{[0.001]^{* * *}}\end{array}$ & $\begin{array}{c}0.017 \\
{[0.001]^{* * *}}\end{array}$ & $\begin{array}{c}-0.002 \\
{[0.001]^{* * *}}\end{array}$ & $\begin{array}{c}0.022 \\
{[0.001]^{* * *}}\end{array}$ & $\begin{array}{l}-0.002 \\
{[0.001]^{* *}}\end{array}$ & $\begin{array}{c}-0.022 \\
{[0.001]^{\star * *}}\end{array}$ \\
\hline School infrastructure & $\begin{array}{c}-0.192 \\
{[0.081]^{* *}}\end{array}$ & $\begin{array}{c}-0.171 \\
{[0.036]^{* * *}}\end{array}$ & $\begin{array}{c}0.011 \\
{[0.071]}\end{array}$ & $\begin{array}{c}0.295 \\
{[0.039]^{* * *}}\end{array}$ & $\begin{array}{c}0.366 \\
{[0.016]^{* * *}}\end{array}$ & $\begin{array}{l}-0.012 \\
{[0.029]}\end{array}$ & $\begin{array}{c}-0.711 \\
{[0.039]^{* * *}}\end{array}$ & $\begin{array}{c}0.811 \\
{[0.024]^{* * *}}\end{array}$ & $\begin{array}{c}0.397 \\
{[0.046]^{* * *}}\end{array}$ \\
\hline $\begin{array}{l}\text { Location dummies } \\
\text { Weights } \\
\text { Observations } \\
\text { Pseudo } \mathrm{R}^{2}\end{array}$ & Sa & $\begin{array}{c}\text { Province } \\
\text { mpling weig } \\
14,565 \\
0.145\end{array}$ & ts & $\mathrm{Sa}$ & $\begin{array}{c}\text { Province } \\
\text { npling weig } \\
24,782 \\
0.084\end{array}$ & ts & & $\begin{array}{c}\text { Province } \\
\text { mpling weig } \\
11,679 \\
0.182\end{array}$ & \\
\hline F-test ( $p$-value) & $\begin{array}{c}0.66 \\
(0.88)\end{array}$ & $\begin{array}{c}0.95 \\
(0.53)\end{array}$ & $\begin{array}{c}1.07 \\
(0.37)\end{array}$ & $\begin{array}{c}0.97 \\
(0.50)\end{array}$ & $\begin{array}{l}1.42 \\
(0.09)\end{array}$ & $\begin{array}{c}0.72 \\
(0.73)\end{array}$ & $\begin{array}{c}0.47 \\
(0.98)\end{array}$ & $\begin{array}{c}1.01 \\
(0.45)\end{array}$ & $\begin{array}{c}0.73 \\
(0.81)\end{array}$ \\
\hline $\begin{array}{l}\text { Int. effect, obs. with } \\
\text { significant Wald Test }\end{array}$ & & 622 & & & 650 & & & 302 & \\
\hline
\end{tabular}

Note: standard error in parenthesis; $* * *, * *$ and * denote significance at the 1,5 and 10 percent confidence level respectively; standard errors adjusted for clustering at the county level; estimation restricted to counties with at least 50 sampled households; the F-test is on the null hypothesis that coefficients estimated when omitting the destination in the header of the column is not different from those reported in the unrestricted specification; the number of observations for which the interaction effect is significant at the 5 percent confidence level is reported.

\section{ConCLusions}

The econmetric analysis presented in this paper provides additional empirical evidence which supports the theoretical prediction that a larger size of migration networks increases the likelihood or the extent of migrants' negative self-selection with respect to education. The migration networks that some Ecuadorian provinces had established with the United States in the past decades influenced the pattern of self-selection of the migrants who left the country in the aftermath of the late-1990s crisis. The multinomial logistic model evidences a negative interaction effect, computed following AI and NORTON [2003], between the number of years of education and the size of migration networks upon the odds ratio of moving to the United States versus staying in Ecuador, which is statistically significant for a subset of would-be migrants. The sorting of Ecuadorian migrants across multiple destinations provides the 
opportunity to dismiss the concern that migration networks might correlate with unobserved county-specific factors that induce a negative migrants' self-selection in education. 


\section{REFERENCES}

Acosta, P., Calderón, C., Fajnzylber, P., LóPez, H., (2008). - «What is the Impact of International Remittances on Poverty and Inequality in Latin America?», World Development, 36:1, pp. 89-114.

Acosta, A., LóPeZ, S., VillamaR, D., (2004). - «Ecuador: Oportunidades y amenazas económicas dela emigración», in F. Hidalgo (ed.), Migraciones, un juego con cartas marcadas, pp. 259-302, Ediciones Abya-Yala, Quito.

AI, C., NORTON, E.C., (2003). - «Interaction terms in logit and probit models», Economics Letters, 80:1, pp. 123-129.

Banco Central del Ecuador, various issues, Cuentas Provinciales, Quito.

BeCKeRMAN, P., (2002). - «Longer-Term Origins of Ecuador's 'Predollarization' Crisis», in P. BECKERMAN and A. Solimano (eds.), Crisis and Dollarization in Ecuador, pp. 17-80, the World Bank, Washington.

BeCKerman, P., CoRTÉs Douglas, H., (2002). - «Ecuador under Dollarization: Opportunities and Risks», in P. BECKeRMAN and A. Solimano (eds.), Crisis and Dollarization in Ecuador, pp. 81-126, the World Bank, Washington.

Beine, M., Docquier, F., Ozden, C., (2009). - «Diasporas», CESifo Working Paper No. 2607, Munich (forthcoming in the Journal of Development Economics).

Beine, M., Docquier, F., RAPOPORT, H., (2008). - «Brain Drain and Human Capital Formation in Developing Countries: Winners and Losers», The Economic Journal, 118:528, pp. 631-652.

BEINE, M., Docquier, F., RAPOPORT, H., (2001). - «Brain drain and economic growth: theory and evidence», Journal of Development Economics, 64, pp. 275-89.

Bertoli, S., Fernández-Huertas Moraga, J., Ortega, F., (2010). - «Immigration Policies and the Ecuadorian Exodus», IZA Discussion Paper No. 4737, Bonn.

Bertoli, S., Fernández-Huertas Moraga, J., ORTegA, F., (2009). - «International Migration Decisions Accounting for Self-Selection», paper presented at the Second Conference on Migration and Development, September, Washington, World Bank.

BORJAS, G., (1988). - «Immigration and self-selection», NBER Working Paper No. 2566, Cambridge, MA.

BORJAS, G., (1987). - «Self-selection and the earnings of immigrants», American Economic Review, 77:4, pp 531-553.

BRown, S.S., (2006). - «Can Remittances Spur Development? A Critical Survey», International Studies Review, 8:1, pp. 55-75.

Calero, C., Bedi, A.S., Sparrow, R., (2009). - «Remittances, Liquidity Constraints and Human Capital Investments in Ecuador», in World Development, 37:6, pp. 1143-1154.

CARrington, W.J., Detragiache E., Vishwanath, T., (1996). - «Migration with endogenous moving costs», American Economic Review, 86:4, pp. 909-930.

ChiquiaR, D., HANSON, G., (2005). - «International migration, self-selection, and the distribution of wages: evidence from Mexico and the United States», Journal of Political Economy, 113:2, pp. 239-281.

CHISWICK, B., (1999). - «Are immigrants favorably self-selected?», American Economic Review - Papers and Proceedings, 89:2, pp. 181-185.

Fernández-Huertas Moraga, J., (2008a). - «New Evidence on Emigrant Selection», IAE Working Paper No. 741.08, Institut d'Anàlisi Economica, Barcelona (forthcoming in the Review of Economics and Statistics).

Fernández-Huertas Moraga, J., (2008b). - «Wealth Constraints, Skill Prices or Networks: What Determines Emigrant Selection?», IAE Working Paper No. 741.08, Institut d'Anàlisi Economica, Barcelona.

Filmer, D., PRITCHETT, L.H., (2001). - «Estimating Wealth Effects Without Expenditure Data-or Tears: an Application to Educational Enrolments in States of India», Demography, 38:1, pp. 115-132.

FLACSO (2004), La emigración internacional en Quito, Guayaquil y Cuenca, Facultad Latinoamericana de Ciencias Sociales, Quito.

GRogGer, J., HANSON, G., (2008). - «Income maximization and the selection and sorting of international migrants», NBER Working Paper No. 13821, Cambridge, MA.

HANSON, G., (2008). - «The Economic Consequences of the International Migration of Labor», mimeo, University of California, San Diego. 
HANSON, G., McINTOSH, C., (2008). - «The Great Mexican Emigration», mimeo, University of California, San Diego (forthcoming in the Review of Economics and Statistics).

Hausman, J., McFadden, D., (1984). - «Specification Tests for the Multinomial Logit Model», Econometrica 52:5, pp. 1219-1240.

Hoefer, M., Rytina, N., BAKeR, B.C., (2008). - «Estimates of the Unauthorized Immigrant Population Residing in the United States: January 2007», Office of Immigration Statistics, Policy Directorate, United States Department of Homeland Security.

IBARRARÁN, P., LUBOTSKY, D., (2007). - «Immigration and Self-Selection: New Evidence from the 2000 Mexican Census», in G.J. BORJAS (ed.), Mexican Immigration to the United States, pp. 159-192, University of Chicago Press.

IMF (2000). - «Ecuador: Selected Issues and Statistical Annex», IMF Staff Country Report No. 00/125, Washington.

Jokisch, B., Pribilsky, J., (2002). - «The Panic to Leave: Economic Crisis and the 'New Emigration' from Ecuador», International Migration, 40:4, pp. 76-101.

Jokisch, B., (2001). - «Desde Nueva York a Madrid: tendencias en la migración ecuatoriana», Ecuador Dedate, 54, pp. 59-84.

KYLE, D., (2000), Transnational Peasants - Migration, Networks and Ethnicity in Andean Ecuador, Johns Hopkins University Press.

LARREA, C., (2004), Pobreza, Dolarización y Crisis en el Ecuador, Ediciones Abya-Yala, Quito.

MCKENZIE, D., RAPOPORT, H., (2007a). - «Self-selection patterns in Mexico-U.S. migration: The role of migration networks», World Bank Policy Research Working Paper No. 4118, Washington (forthcoming in the Review of Economics and Statistics).

MCKenZiE, D., RAPOPORT, H., (2007b). - «Network effects and the dynamics of migration and inequality: Theory and evidence from Mexico», Journal of Development Economics, 84:1, pp. 1-24.

MOUNTFORD, A., (1997). - «Can a brain drain be good for growth in the source economy?», Journal of Development Economics, 53, pp. 287-303.

MUNSHI, K., (2003). - «Networks in the Modern Economy: Mexican Migrants in the US Labor Market», Quarterly Journal of Economics, 118, pp. 549-599.

ORRENiUS, P.M., ZAVODNY, M., (2005). - «Self-selection among undocumented immigrants from Mexico», Journal of Development Economics, 78, pp. 215-240.

Ortiz Moya, R., Guerra PÁEZ, V., (2008), Caracterización sociodemográfica y económica de las y los emigrantes Ecuatorianos, INEC, Quito.

Ramírez Gallegos, F., Ramírez, J.P., (2005), La Estampida Migratoria Ecuatoriana: Crisis, redes transnacionales y repertorios de acción migratoria, UNESCO and Ediciones Abya-Yala, Quito.

RoY, A.D., (1951). - «Some thoughts on the distribution of earnings», Oxford Economic Papers, 3:2, pp. $135-146$.

Ruggles, S., Sobek, M., Trent, A., Fitch, C.A., Goeken, R., Kelly Hall, P., King, M., Ronnander, C., (2008), Integrated Public Use Microdata Series: Version 4.0 [Machine-readable database]. Minnesota Population Center, Minneapolis.

SÁNCHEZ, J., (2004). - «Ensayo sobre la economia de la emigración en Ecuador», Ecuador Debate, 63, pp. 47-62.

United States, Department of Homeland SeCURITY, various issues, Yearbook of Immigration Statistics. Washington: US Department of Homeland Security, Office of Immigration Statistics.

ÜNALAN, T., (2005). - «Definition of Household Membership in International Migration Surveys», Journal of Social Sciences, 1, pp. 220-225.

VIDAL, J-P., (1998). - «The effect of emigration on human capital formation», Journal of Population Economics, 11, pp. 589-600.

WoodrufF, C, ZENTENo, R.M., (2007). - «Migration networks and microenterprises in Mexico», Journal of Development Economics, 82:2, pp. 509-528.

WORLD BANK (2008), World Development Indicators 2008, Washington. 